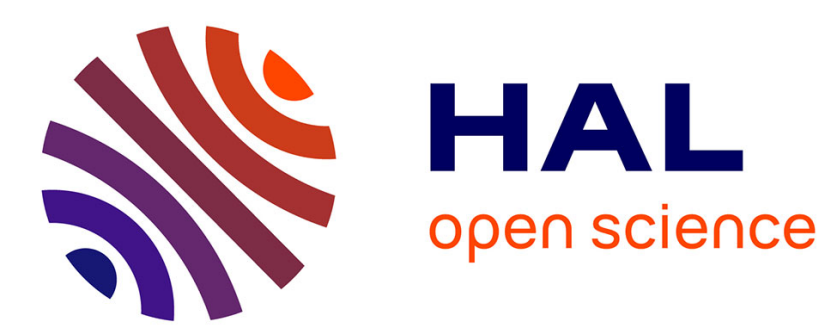

\title{
Assessment of dietary intake of polychlorinated biphenyls from a total diet study conducted in Pavia, Northern Italy
}

Roberta Turci, Giovanna Turconi, Sergio Comizzoli, Carla Roggi, Claudio Minoia

\section{To cite this version:}

Roberta Turci, Giovanna Turconi, Sergio Comizzoli, Carla Roggi, Claudio Minoia. Assessment of dietary intake of polychlorinated biphenyls from a total diet study conducted in Pavia, Northern Italy. Food Additives and Contaminants, 2006, 23 (09), pp.919-938. 10.1080/02652030600699296 . hal-00577587

\section{HAL Id: hal-00577587 \\ https://hal.science/hal-00577587}

Submitted on 17 Mar 2011

HAL is a multi-disciplinary open access archive for the deposit and dissemination of scientific research documents, whether they are published or not. The documents may come from teaching and research institutions in France or abroad, or from public or private research centers.
L'archive ouverte pluridisciplinaire HAL, est destinée au dépôt et à la diffusion de documents scientifiques de niveau recherche, publiés ou non, émanant des établissements d'enseignement et de recherche français ou étrangers, des laboratoires publics ou privés. 


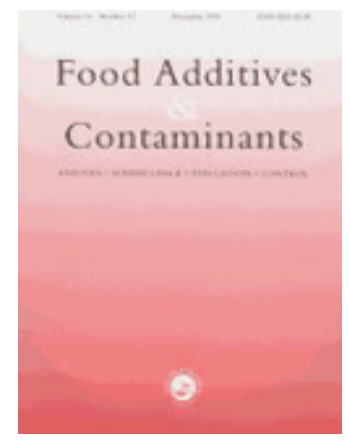

\section{Assessment of dietary intake of polychlorinated biphenyls from a total diet study conducted in Pavia, Northern Italy}

\begin{tabular}{|r|l|}
\hline Journal: & Food Additives and Contaminants \\
\hline Manuscript ID: & TFAC-2005-308.R1 \\
\hline Manuscript Type: & Original Research Paper \\
\hline Complete List of Authors: & O6-Mar-2006 \\
\hline & $\begin{array}{l}\text { Turci, Roberta; Salvatore Maugeri Foundation, Laboratory for } \\
\text { Environmental and Toxicological Testing } \\
\text { Turconi, Giovanna; University of Pavia, Department of Applied } \\
\text { Sciences, Section of Human Nutrition and Dietetics, Faculty of } \\
\text { Medicine } \\
\text { Comizzoli, Sergio; University of Pavia, Department of Applied } \\
\text { Sciences, Section of Human Nutrition and Dietetics, Faculty of } \\
\text { Medicine } \\
\text { Roggi, Carla; University of Pavia, Department of Applied Sciences, } \\
\text { Section of Human Nutrition and Dietetics, Faculty of Medicine } \\
\text { Minoia, Claudio; Salvatore Maugeri Foundation, Laboratory for } \\
\text { Environmental and toxicological Testing }\end{array}$ \\
\hline Methods/Techniques: & Total diet studies, GC/MS \\
\hline Additives/Contaminants: & PCBs \\
\hline Food Types: & \multicolumn{2}{|l}{} \\
\hline &
\end{tabular}

\section{SCHOLARONE Manuscripts}




\section{Assessment of dietary intake of polychlorinated biphenyls from a total diet study conducted in Pavia, Northern Italy}

Roberta Turci $^{1}$, Giovanna Turconi ${ }^{2}$, Sergio Comizzoli ${ }^{2}$, Carla Roggi ${ }^{2}$, Claudio Minoia $^{1}$

${ }^{1}$ Laboratory for Environmental and Toxicological Testing

Salvatore Maugeri Foundation, via S. Maugeri 6, 27100 Pavia, Italy

${ }^{2}$ Department of Applied Health Sciences

Section of Human Nutrition and Dietetics, Faculty of Medicine, University of Pavia, Via Bassi 21, 27100 Pavia, Italy.

Correspondence: Roberta Turci, Laboratory for Environmental and Toxicological Testing, Salvatore Maugeri Foundation - via S. Maugeri 6, 27100 Pavia, Italy, Tel +390382 592 312, fax +390382 592067.

E-mail: rturci@fsm.it 


\begin{abstract}
Diet is considered to be the main source of body burden of PCBs in the general population. The most cost-effective and reliable way to estimate the dietary intake is based on total diet studies. The aim of the present study was to provide a reliable estimate of recent average dietary intakes of PCBs in Northern Italy. Congener-specific analysis of PCBs were undertaken on total diet samples collected at the Pavia University cafeteria. The average daily intake for total PCBs was calculated to be $0.26 \mu \mathrm{g} /$ person/day. The major contributor to PCB intake was accounted for by pooled samples of bread, cereals and potatoes, followed by the protein composite and fruit and vegetables. Although diverse dietary habits, and differences in sampling and analytical procedures, make comparison between different studies difficult, the daily intake of PCBs in Northern Italy can be located in the lower part of the range for values reported in the literature.
\end{abstract}

Keywords: Polychlorobiphenyls (PCBs), congeners, dietary intake, total diet study, Northern Italy 


\section{Introduction}

Polychlorinated biphenyls (PCBs) comprise 209 individual chlorinated biphenyl rings, called congeners. They were typically manufactured as mixtures of up to 180 different congeners (Ishikawa et al., 2005). However, after release into the environment, the composition of commercial PCB mixtures are altered through volatilization and other kinds of partitioning, chemical or biological transformation, and preferential bioaccumulation (Bakker et al. 2003). Furthermore, 36 congeners of highest concern were identified and classified, based on potential for toxicity and frequency of occurrence in environmental samples (McFarland and Clarke 1989).

Because of their persistence, PCBs are present in all environmental media. For example, the higher chlorinated congeners, adsorb strongly to sediment and soil, where they tend to persist for long periods of time. Congeners with low chlorine content tend to be more volatile and also more soluble in water. In addition, due to their stability and lipophilicity, PCBs bioaccumulate in food chains and are stored in fatty tissues (EPA 1979, 1983, 1988, Eisenreich et al 1983, 1992, Pearson 1996).

The ability of PCBs to be degraded or transformed in the environment as well as their biological and toxic effects depend on the degree of chlorination and on the isomeric substitution pattern (Bohm et al. 1993, Hansen 1998). Human PCB exposure has been attributed to inhalation of polluted air and ingestion of contaminated food. In fact, diet has been and continues to be the major source of body burden of PCBs in the general population (Focant et al. 2002).

Because of their lipophilicity, PCBs enter the food chain and become progressively concentrated from small organisms to larger fish and mammals. Most PCBs tend to accumulate mainly in fatty tissue in fish and to a less extent in edible muscle tissue (Lazaro et al. 1999). Foods most likely to contain PCBs include chicken, turkey, beef, eggs, and dairy products. 
Since 1977 when manufacturing of PCBs was banned, levels in most foods have declined. Nevertheless, regular surveillance programmes on PCBs in the diet must be carried out to keep the situation under control. Currently, PCBs in foodstuffs are routinely monitored in several countries and maximum tolerance levels have been set for PCBs (total PCBs or congener-specific data) in edible products (Himberg et al. 1993, Lazaro et al. 1999).

Both acute and chronic health effects may be observed after exposure to PCBs. Short term effects, such as throat, nose and eye irritation, may occur immediately or shortly after exposure. High exposures, as well as repeated (chronic) exposures can even damage the liver (ATSDR 2000). Long term effects can occur at some time after exposure and can last for months or years. PCBs may be teratogen in humans, and they may be passed to a child through mother's milk. In addition, PCBs can affect the reproductive system of adults (ATSDR 2000, Faroon et al. 2001b). High exposures can damage the nervous system, causing numbness, weakness, and tingling in the arms and legs. Finally, PCBs can cause a severe acne like rash (chloracne).

With regard to cancer potential of PCB mixtures, there is limited (IARC 1987) or inadequate (US EPA 1996) evidence of carcinogenity in humans (Faroon et al. 2001a). However, animal studies provide sufficient evidence of carcinogenicity (IARC, 1987, US EPA 1996). Some commercial mixtures have thus been characterized as probably carcinogen to humans (IARC 1987). Of the 209 congeners of PCBs, a small number have been reported as having "dioxin-like" toxicity. As with the dioxins, the concentrations of these congeners are assigned a weighting factor based on their relative toxicities compared to the most toxic dioxin congener 2,3,7,8-TCDD. The sum of the weighted concentrations forms the "Toxic Equivalent Quantity" or TEQ (Safe 1990, World Health Organization (WHO) 1993, van der Berg et al. 1998).

During the last ten years, several studies have been carried out to evaluate dietary exposure to PCBs, polychlorodibenzo-p-dioxins (PCDDs) and 
polychlorodibenzofurans (PCDFs) in the general population. Most available data concerning daily dietary intake (PCDDs + PCDFs + PCBs), are reported in terms of Toxic WHO-TEQs (Ahlborg et al. 1994). In 1998, the WHO consultation recommended a Tolerable Daily Intake (TDI) for dioxins and dioxin-like PCBs of 1-4 pg WHO-TEQ/kg body weight (van Leeuwen and Younes 1998, 2000, WHO 1998). Since dioxins and PCBs have very long half-lives in the human body, the Scientific Committee for Food (SCF) suggested that the tolerable intake should be expressed on a weekly rather than a daily basis. In 2001, the SCF established a tolerable weekly intake (TWI) of $14 \mathrm{pg} \mathrm{WHO-TEQ/kg} \mathrm{body} \mathrm{weight.}$ TDI and TWI have been set using a precautionary approach and are recommended as a tool for long term safety assessment (van Leeuwen and Younes 2000).

The most cost-effective and reliable way to estimate the dietary intake of PCBs is based on Total Diet Studies (TDS) (Peattie et al. 1983, Pennington and Gunderson, 1987, Pennington et al. 1996). This method has been widely used in several European and non-European Countries. To make total diet studies random, samples of food are usually collected in representative centers and weighed out in the proportions in which they are consumed in the diet. This approach is particularly important because it determines levels of the analytes in foods as they would be consumed, so that they resemble as much as possible the normal character of the diet. Moreover, it is suitable for estimating the dietary intake of compounds which may be changed as a result of washing, peeling and cooking. The average daily intake of PCBs was thus calculated based on food consumption frequency, portion size, and PCB levels in foodstuffs.

The aim of the present study was to provide a reliable estimate of recent average dietary intakes of PCBs in an area of Northern Italy. For this purpose, congener-specific analysis of PCBs were undertaken on total diet samples collected at the Pavia University cafeteria. The results obtained were then compared with average dietary intakes previously estimated in other areas. 


\section{Materials and methods}

Food sampling

Raw, cooked, and ready-to-eat foods were collected over two consecutive weeks in July 2004, at the University cafeteria located in Pavia, Northern Italy. This big cafeteria prepares about two thousands meals a day. Some traditional breakfast foods, such as biscuits, sweets, and cereals, which were not served at the cafeteria, were purchased at three local supermarkets. All the foodstuffs (226 from the cafeteria and 22 from the supermarket) are listed in Table I.

Each sample was given a name, a number code and the list was kept on record. Collected items were immediately transferred to the laboratory where the pre-analytical treatment was performed. In the present study, the choice of the foods and their consumption values have been based on the Italian Household National Survey carried out in 1994-96 (Turrini et al. 2001). This survey is the most representative Italian food consumption study since it covered 1978 subjects randomly selected in Northern-Western Italy.

Foodstuffs representing the same food category were finally aggregated into five different food groups:

- Bread, cereals and potatoes

- Meat and meat products, fish and fish products, eggs, legumes (protein composite)

- Milk and dairy products

- Fruit and vegetables

- Beverages (soft and alcoholic drinks, including mineral water)

\section{Standards and reagents}

Sixty-one individual congeners $(10 \mathrm{ng} / \mu \mathrm{l}$ in iso-octane) were purchased from $\mathrm{Dr}$. Ehrenstorfer Laboratories (Ausburg, Germany). All solvents (hexane, diethyl ether, acetone, and iso-octane) were pesticide grade (Merck, Darmstadt, 
Germany). Double-distilled water was produced from a Milli-Q Plus water purification system.

\section{Sample preparation}

Food samples, except for dairy products and beverages, were slightly thawed and cut into pieces. They are then pooled and homogenized with doubledistilled and deionised water until completed pureed, by a STERILMIXER blender (pbi international). The samples were stored in polyethylene containers and frozen at $-18^{\circ} \mathrm{C}$ until analysis.

PCBs were analysed according to the method described and validated by Turci et al. $(2002,2004)$ for the determination of 60 congeners in serum, with modifications (mainly due to the different matrix).

Approximately $10 \mathrm{~g}$ (wet weight) of homogenate were ground with anhydrous sodium sulphate and spiked with 2,2',3,4,5,6'-hexachlorobiphenyl (\#143) as the internal standard. For beverages, $20 \mathrm{~mL}$ of each sample were analysed. The samples were then extracted twice with a $10-\mathrm{mL}$ aliquot of an $n$-hexane-diethyl ether mixture 3:1, v/v. After each addition, the samples were shaken and then sonicated for half an hour. The organic layers were combined, concentrated to a final volume of $5 \mathrm{~mL}$, and cleaned by solid phase extraction (SPE) in disposable cartridges. Varian BondElutß Silica and Florisil (packing $1 \mathrm{~g} / 6 \mathrm{~mL}$ column reservoir) SPE tubes were used (Varian Canada Inc., ON, Canada). A Silica tube was attached to the lower end of a Florisil tube using an adapter. Both the SPE Cartridges had been pre-conditioned with $10 \mathrm{~mL}$ of hexane. After the sample loading, PCBs were finally eluted with two 5-mL aliquots of hexane. The solvent was evaporated off under a nitrogen stream and the residue was dissolved in $100 \mu \mathrm{L}$ of iso-octane before injection into the GC/MS. Test materials, fortified with target compounds, have been analyzed to demonstrate precision and accuracy of the analyses.

\section{Apparatus and analytical conditions}


A Supelco (Bellefonte, PA, USA) Visiprep ${ }^{\mathrm{TM}}-\mathrm{DL}$ solid phase extraction (SPE) vacuum manifold was used to simultaneously process up to 24 samples. Varian BondElut® Silica and Florisil (packing $1 \mathrm{~g} / 6 \mathrm{~mL}$ column reservoir) SPE tubes were used (Varian Canada Inc., ON, Canada).

A Hewlett Packard (Palo Alto, CA, USA) 5890 Series II Plus GC equipped with an HP 7673 auto sampler and interfaced with a mass spectrometer was used for gas chromatographic separation. A $50 \mathrm{~m} \times 0.2 \mathrm{~mm} \times 0.5 \mu \mathrm{m}$, J\&W $100 \%$ dimethylpolysiloxane PONA capillary column (J\&W Scientific Columns from Agilent Technologies) was used with helium as carrier gas at a constant flow of $0.8 \mathrm{~mL} / \mathrm{min} .1 \mu \mathrm{L}$ was injected in splitless mode with the split outlet opened after 0.7 min. Injector and detector temperatures were set at $270^{\circ} \mathrm{C}$ and $280^{\circ} \mathrm{C}$, respectively. The oven temperature was programmed as follows: $150^{\circ} \mathrm{C}$ for 1 $\min , 50^{\circ} \mathrm{C} / \min$ to $200^{\circ} \mathrm{C}$, then $5^{\circ} \mathrm{C} / \mathrm{min}$ to $300^{\circ} \mathrm{C}$ and $8 \mathrm{~min}$ hold at $300^{\circ} \mathrm{C}$.

The mass spectrometer (HP 5972, Palo alto, CA, USA) operated in electron ionisation mode $(\mathrm{El})$ at $70 \mathrm{eV}$. The MS was tuned on PFTBA by optimizing the signals at $\mathrm{m} / \mathrm{z} 209,414$, and 512. A SIM program was constructed for GC-MS acquisition and quantification. Two ions $\left(\mathrm{M}^{+}\right.$and $[\mathrm{M}+2]^{+}$ions) were monitored for each level of chlorination. Retention time, masses and relative abundance of the confirmation ion to the target ion were used as identification criteria.

The samples were analysed for the following PCB congeners (Ballschmiter \& Zell numbering) \#18, 21, 28, 30, 31, 37, 44, 47, 49, 52, 61, 66, 70, 74, 77, 81, $87,97,99,101,105,110,114,118,119,123,126,128,138,143,146,149$, $151,153,156,157,158,167,168,169,170,171,172,177,178,180,183,187$, 189, 190, 193, 194, 195, 196, 199, 201, 202, 206, 207, 208, 209.

These congeners have been selected on the basis of their toxicity and their frequency of occurrence in environmental and biological samples.

Dietary intake estimation 
PCB intakes (ng/day) were estimated by multiplying their concentrations in any one food item ( $\mathrm{ng} / \mathrm{kg}$ ) by the amount of that food consumed, expressed as grams of food/day or millilitre of beverage/day. Total intake of PCBs is then obtained by summing the intakes from all food items.

\section{Results}

The GC/MS method employed for the determination of PCBs in foodstuffs proved to be reliable, with a $\mathrm{CV}<20 \%$ for all the analytes. The method was also shown to be accurate with a relative error $<14 \%$ for both inter- and intra-day experiments. Recoveries were estimated to range from 65 to $80 \%$, depending on the specific congener considered. Selectivity was assessed through analysis of equipment blanks to ensure that there were no interferences.

The limit of detection for each individual PCB congener in foodstuffs and in beverages was calculated to be $1 \mathrm{ng} / \mathrm{kg}$ and $0.3 \mathrm{ng} / \mathrm{L}$, respectively. In the case of samples whose concentration level was below the detection limit, the value was computed as zero. Due to the large number of non-detected congeners, inclusion of half LOD values in the total PCB calculations would result in a high degree of uncertainty (US EPA 1999).

Results on the analysis of foodstuffs for individual PCB isomers are given in Tables II a-c. In no sample were octa-, nona-, and deca-PCBs detected. Individual congeners were added together to yield total PCB concentrations. The average level of total PCBs was $4.5 \mathrm{ng} / \mathrm{kg}$ for beverages, $58 \mathrm{ng} / \mathrm{kg}$ for dairy products, $154 \mathrm{ng} / \mathrm{kg}$ for fruit and vegetables, $224 \mathrm{ng} / \mathrm{kg}$ for bread, cereals, and potatoes, and $540 \mathrm{ng} / \mathrm{kg}$ for the protein composite. The most abundant congeners (in terms of food concentration) in the different food categories were \# 118 (bread, cereals, and potatoes), 101 (protein composite), 180 (dairy products), 156 (fruit and vegetables), and 47 (beverages).

In Tables III a-g, the estimated daily intake (EDI) of PCBs from different foods (ng/day), are reported. Figure 1 illustrates the data in bar graph format, with the 
average daily intake expressed in ng/person/day for the 21 congeners detected above the detection limit. The concentrations ranged from 2.9 to 34.7 ng/person/day. The predominant congener was \# 101, followed by \# 138 and \# 153. The less abundant isomers were \# $99<183<66$.

The total PCB content was obtained by summation of all the individual congeners. The average daily intake for total PCBs was calculated to be 0.26 $\mu \mathrm{g} /$ person/day (range: $0.15-0.48 \mu \mathrm{g} /$ person/day). The sum of dioxin like PCBs was $39.7 \mathrm{ng} /$ person/day on average (range: 38.0 - $41.5 \mathrm{ng} /$ person/day). Among dioxin-like PCBs, only \# 118, 105, and 156 were detected above the detection limit. In no samples were non-ortho coplanar PCB congeners found.

Based on the results from this survey, the contribution from different classes of foodstuffs to the intake of PCBs in the Italian (local) diet is illustrated in Figures 2 and 3. The major contribution toward PCB intake is accounted for by pooled samples of bread, cereals, and potatoes (44.8\%), followed by the protein composite (33.4\%), and fruit and vegetables (19.1\%). If considering dioxin-like PCBs, bread, cereals and potatoes shared $89.8 \%$ of the total intakes of these congeners, followed by fruit and vegetables (9.9\%).

\section{Discussion and conclusions}

The primary route of human exposure to PCBs for the general population is through consumption of food. The dietary intake of PCBs is estimated to account for greater than $90 \%$ of human exposure to these substances (DuarteDavidson and Jones 1994, Liem et al. 2000).

Levels of PCBs in foods and dietary exposures to these compounds have been reported in the international literature (Mes et al. 1989, Kannan et al. 1992a, 1992b, 1994, Duarte-Davidson and Jones 1994, Schecter et al. 1997, Freijer et al. 2001, Tsutsumi et al. 2001, Costabeber et al. 2005, Huwe and Larsen 2005). Very limited information is available on dietary exposure to PCBs in Italy (Fasola et al. 1998, Zuccato et al. 1999, Binelli and Provini 2003, 2004, Ghidini 
et al. 2005). In general, earlier studies determined levels of PCBs in retail milk products, fish, and meat.

Studies to investigate levels of PCBs in a broader range of foods are needed. In addition, no Total Diet Studies (also known as Market Basket Surveys) were conducted to assess dietary intake of PCBs of the Italian population. The duplicate portion method was used by Zuccato et al. (1999) to measure the daily dietary intake of PCBs for a population group living in Abruzzi, Central Italy. This is the most accurate approach in estimating the actual exposure to contaminants. Nevertheless, duplicate portion studies have the disadvantages of only covering a short period of time and a restricted population.

This paper reports the findings from a survey to determine PCBs in foods widely consumed in an area of Northern Italy. This study analyzed ready-to-eat foods collected at the University cafeteria located in Pavia, Northern-Western Italy. The main objective of this study was not only to estimate the dietary intake of PCBs for an Italian population group, but also to allow the Italian dietary exposure to PCBs to be compared with similar international dietary studies. Nevertheless, due to differences in sampling and analytical procedures used and the range of congeners being assessed, direct comparison between different diets was difficult.

Moreover, PCB concentrations are sometimes expressed as sum of all PCBs ( $\Sigma$ PCBs) or as sum of marker PCBs analyzed (e.g. $\Sigma 7 P C B s$, sum of seven marker PCBs). When only dioxin-like congeners are considered, PCB concentrations are expressed as TEQ. In addition, concentrations of PCBs can be expressed per wet weight (w.w.), or on a fat (lipid) weight basis. Reporting of non-quantified congeners also varies between different published studies.

Existing literature suggests that meat, fish, and poultry are the primary sources of PCBs in the human diet with fish being the major contributing factor (Schecter et al. 1997, Joint FAO/WHO 2001). In general, high levels of PCBs 
are found in high-fat foods, and the lowest in low-fat foods such as fruits and vegetables. The congener specific PCB concentrations, expressed as $\mathrm{ng} / \mathrm{kg}$ w.w., in the different foodstuffs collected within our study site, are summarised in Tables Ila-c.

Out of 60 , only 21 congeners were quantified above the detection limit using HRGC interfaced with low resolution mass spectrometry. The most abundant congeners (in terms of concentration) in the different food groups resulted to be \#118 for bread, cereals and tubers; \#101 for the protein composite; \#180 for dairy products; \#156 for fruit and vegetables, and \#47 for beverages.

It can be seen that less chlorinated congeners can be found in low fat food, while penta-, hexa-, and hepta- chlorinated CBs are more frequently quantified in high-fat foodstuffs, like meat and fish. As for total PCBs (sum 60 congeners), it was noted that the highest levels were found in the protein composite, followed by cereals and tubers, fruit and vegetables, dairy products, and beverages. It should be highlighted that mean values have been calculated excluding limits of detection for non-quantified isomers.

Dioxin-like congeners were detected in pasta with seafood (\#118, 105, and $156)$, pork meat (\#118), vegetables (\#156), and yogurt (\#156). Dioxin-like and EC7 (\#28, 52, 101, 118, 153, 138 and 180) PCBs accounted for a mean percent of total PCB concentrations in foodstuffs of $8.6 \%$, and $57.3 \%$, respectively.

On the basis of information obtained from the Italian Household National Survey (Turrini et al. 2001), concerning the average daily food consumption in Italy, and using the PCB concentration measured in the individual foodstuffs (reported in Tables Ila-c), the average daily intake of individual PCB congeners can be estimated. The results are presented in Tables III a - $\mathrm{g}$.

Figure 1 shows the average concentration (ng/day) profile for all the foodstuffs collected in Pavia. The major contributor is PCB \#101, followed by \#138, 153, 
47, 118, 180, and 52. The isomer composition of PCB in different groups of foodstuffs is shown in Figure 2. For example, it can be seen that congeners \#118, 105, 99, 156, and 70 are mainly ingested through the consumption of bread, cereals, and potatoes. Intake of isomers \#183, 110, 101, 47, and 31 is mainly due to the protein composite. Dietary intake through fruit and vegetables appears to be important mainly for a few lower chlorinated congeners, especially \#28 and 66. Intake through beverages is negligible. Total PCB intake was then obtained by summing the intakes from all foodstuffs containing the PCB congener concerned. In the present study, the average adult daily intake (AADI) was estimated to be $0.26 \mu \mathrm{g} /$ person/day total PCB (range: $0.15-0.48$ $\mu \mathrm{g} /$ person/day). Dividing by the average body weight of $65 \mathrm{~kg}$, the AADI resulted to be $4.0 \mathrm{ng} / \mathrm{kg}$ body weight/day.

The TEQ intake, calculated using factors suggested by the WHO (van der Berg et al. 1998) and using the total of the mean concentration of congeners \# 118, 105, and 156 (excluding LOD values) was 9.7 pg/person/day. Average daily food intake of TEQs for an adult weighting $65 \mathrm{~kg}$ was estimated to be $0.15 \mathrm{pg}$ WHO-TEQ/kg body weight/day. In this respect, it is noteworthy that recent reports suggested that high concentrations of the summation of mono-ortho congeners PCBs 105, 118, and 156 in adipose tissue and plasma, may be associated with the risk of breast cancer (Aronson et al. 2000, Demers et al. 2002).

The relative contribution of foodstuffs groups to the dietary intake is illustrated in Figures $3 \mathrm{a}$ and $3 \mathrm{~b}$. The three major contributors to the total PCB intake are bread, cereals, and potatoes (44.8\%), the protein composite (33.4\%), and fruit and vegetables (19.1\%). In contrast to much of the existing literature, fish, meat and dairy products are not the prime source of dietary intake of PCBs in the area at issue. As far as dioxin-like PCBs are concerned (Figure 3b), the major contributors are cereals, which accounted for $89.8 \%$, followed by fruit and vegetables $(9.9 \%)$, and dairy products $(0.3 \%)$. It must be underlined that dioxinlike congeners \#118, 105, and 156 were quantified in pasta with seafood, which 
was included in the cereals group. In fact, the presence of these mono-ortho isomers may be due to seafood.

Finally, it should be noted that bread, cereals, and potatoes are not the most contaminated food but they contribute significant proportions of the PCB intake because they are major components of diet, at least in Northern Italy. Although different dietary habits make direct comparison with results from studies in other countries difficult, the daily intake of PCBs in Northern Italy is consistently lower than that of other countries where comparable studies have been undertaken (Table IV). However, EDIs can hardly be compared because of different dietary habits in diverse countries and the studies refer to different reference years. For example, in Japan (Matsumoto et al. 1987, Akutsu et al. 2005, Koizumi et al. 2005) and Finland (Moilanen et al. 1986) fish and seafood were the major contributors to PCB intake, as found for the UK (Duarte-Davidson and Jones 1994, Juan et al. 2002). In Thailand (Tanabe et al. 1991), Vietnam (Kannan et al. 1992a) and India (Kannan et al. 1992b) foodstuffs of agricultural origin gave the highest contribution to PCB intakes. Australia (Kannan et al. 1994), Canada (Mes et al. 1989, Gilman et al. 1995, Newsome et al. 1998), New Zealand (Buchland et al. 1998), and the USA (Gunderson 1988) are characterized by a high consumption of meat, which is the main source of PCB in diet. Dairy products resulted to be the primary source of dietary intake of PCBs in Germany (Brunn et al. 1989).

Of course, the daily intake also varies depending on the dietary habits of each individual. For example, people consuming no meat or fish products, like vegetarians, nor dairy products, like vegans, would be expected to have lower levels of PCB exposure through their diet. In addition, the congener profile may change, being their PCB intakes dominated by the lower chlorinated congeners found mainly in vegetables. Another key consideration in comparing intakes based on an "amount per body weight per day" is the actual body weight used in the particular study. The body weights used in the studies compared may vary from a $60 \mathrm{~kg}$ person up to $80 \mathrm{~kg}$. 
Furthermore, in most studies food samples were analysed for PCB content as purchased. It should be noted that food preparation and/or cooking method can alter PCB levels in the final food product. For example, cooking has been found to reduce PCB levels by $23-41 \%$ (Zabik et al. 1996). That is why direct comparison of the results from different surveys may be not always straightforward. The intakes estimated in this study are also below the recently established World Health Organisation tolerable daily intake (TDI) range of 1-4 pg TEQ/kg bw/day (WHO 1998).

Nevertheless, the WHO-TDI range has been created for exposure to polychlorinated dibenzo-p-dioxins (PCDDs), polychlorinated dibenzofurans (PCDFs) and dioxin-like PCBs. The dioxin-like PCBs contribution to the total TEQ has been evaluated to represent about $50 \%$. Our result should therefore be doubled before comparison with the recommended WHO-TDI. However, the value obtained in this study appears to be located in the lower part of the range for reported values.

In light of the above, the results from the present study can be useful as a set of reference data for exposure to PCBs of general population in a Northern-Italy area. Currently, a very few data are available for Italian population groups and moreover congener-specific data for foodstuffs are limited. Since chemical contamination of food is considered to be a major public health concern, WHO recognizes the need for all countries to undertake TDS to assure that food does not contain chemicals that would cause short- or long-term health problems. Despite declining trends are observed, there is therefore a need for monitoring PCBs (and possibly PCDDs/Fs) in foodstuffs collected in different geographical areas in Italy in an attempt to compute their typical dietary intakes.

\section{References}


Ahlborg UG, Becking GC, Birnbaum LS, Brouwer A, Derks HJGM, Feeley M, Golor G, Hanberg A, Larsen JC, Liem AKD, Safe SH, Schlatter C, Wærn F, Younes M, Yrjånheikki E. 1994. Toxic equivalency factors for dioxinlike PCBs. Chemosphere, 28(6):1049-1067.

Akutsu K, Kuwabara K, Konishi Y, Matsumoto H, Murakami Y, Tanaka Y, Matsuda R, Hori S. 2005. [Congener-specific analysis of Pcbs in food samples by using GC/MS] Shokuhin Eiseigaku Zasshi. Jun;46(3):99-108.

Aronson KJ, Miller AB, Woolcott CG, Sterns EE, McCready DR, Lickley LA, Fish EB, Hiraki GY, Holloway C, Ross T, Hanna WM, SenGupta SK, Weber JP. 2000. Breast adipose tissue concentrations of polychlorinated biphenyls and other organochlorines and breast cancer risk. Cancer Epidemiol Biomarkers Prev. Jan;9(1):55-63.

ATSDR. 2000. Toxicological profile for polychlorinated biphenyls, Atlanta, GA: US Department of Health and Human Services, Agency for Toxic Substances and Disease Registry.

Bakker MI, Baars AJ, Baumann RA, Boon PE, Hoogerbrugge R. 2003. Indicator PCB's in Foodstuffs:Occurrence and Dietary Intake in The Netherlands at the End of the Twentieth Century. RIKILT report 2003.014 RIVM 639102025/2003, Bilthoven, The Netherlands.

Ballschmitter K, Zell M. 1980. Analysis of polychlorinated biphenyls (PCB) by glass-capillary gas-chromatography. Composition of technical AroclorPCB and Clophen-PCB mixtures. Fresenius Z Anal Chem 302:20-31

Binelli A, Provini A. 2004. Risk for human health of some POPs due to fish from Lake Iseo. Ecotoxicol Environ Saf. May;58(1):139-45.

Binelli A, Provini A. 2003. POPs in edible clams from different Italian and European markets and possible human health risk. Mar Pollut Bull. Jul;46(7):879-86.

Bohm V, Schulte E, Thier H-P. 1993. Polychlorinated biphenyl residues in food and human milk: Determination of co-planar and mono-ortho substituted congeners. Z Lebensm Unters Forsch 196(5):435-440. 
Brunn H, Georgii S, Stojanowic V, Flemming R, Thalacker R. 1989. Fremdstoffe in Lebensmitteln - Ermittlung einer täglichen Aufnahme mit der Nahrung. Deutsche Lebensmittel-Rundschau 85: 239-246.

Buckland SJ, Scobie S, Heslop V. 1998. Organochlorines in New Zealand: Concentrations of PCDDs, PCDFs and PCBs in retail foods and an assessment of dietary intake for New Zealanders. A report for the Ministry for the Environment, Wellington, New Zealand.

Costabeber I, Dos Santos JS, Xavier AA, Weber J, Leaes FL, Bogusz S Junior, Emanuelli T. 2005. Levels of polychlorinated biphenyls (PCBs) in meat and meat products from the state of Rio Grande do Sul, Brazil. Food Chem Toxicol. Oct 7;

Demers A, Ayotte P, Brisson J, Dodin S, Robert J, Dewailly E. 2002. Plasma concentrations of polychlorinated biphenyls and the risk of breast cancer: a congener-specific analysis. Am J Epidemiol. Apr 1;155(7):629-35.

Duarte-Davidson R, Jones KC. 1994. Polychlorinated biphenyls (PCBs) in the UK population: estimated intake, exposure and body burden. Sci Total Environ 151: 131-52.

Eisenreich SJ, Capel PD, Looney BB. 1983. PCB dynamics in Lake Superior water. In: Mackay D, ed. Physical behavior of PCBs in the Great Lakes. Ann Arbor, Ml: Ann Arbor Science Press, 181-211.

Eisenreich SJ, Baker JE, Franz T, et al. 1992. Atmospheric deposition of hydrophobic organic contaminants to the Laurentian Great Lakes. In: Schnoor JL, ed. Fate of pesticides and chemicals in the environment. New York, NY: John Wiley \& Sons, Inc., 51-78.

EPA. 1979. Water-related environmental fate of 129 priority pollutants, Vol. II. Washington, DC: U.S. Environmental Protection Agency, 40-2 to 43-10. EPA 440/4-79-029a.

EPA. 1983. Environmental transport and transformation of polychlorinated biphenyls. Washington, DC: U.S. Environmental Protection Agency, Office of Pesticides and Toxic Substances. EPA-560/5-83-025. PB84142579. 
EPA. 1988. Drinking water criteria document for polychlorinated biphenyls (PCBs). Cincinnati, OH: U.S. Environmental Protection Agency, Office of Health and Environmental Assessment, Environmental Criteria and Assessment Office. ECAO-CIN-414.

Faroon OM, Keith S, Jones D, De Rosa C. 2001a. Carcinogenic effects of polychlorinated biphenyls. Toxicol Ind Health. Mar;17(2):41-62.

Faroon OM, Keith S, Jones D, de Rosa C. 2001b. Effects of polychlorinated biphenyls on development and reproduction. Toxicol Ind Health. Apr;17(3):63-93.

Fasola M, Movalli PA, Gandini C. 1998. Heavy metal, organochlorine pesticide, and PCB residues in eggs and feathers of herons breeding in northern Italy. Arch Environ Contam Toxicol. Jan;34(1):87-93.

Focant JF, Pirard C, Thielen C, De Pauw E. 2002. Chemosphere 48(8): 763770.

Freijer JI, Hoogerbrugge R, van Klaveren JD, Traag WA, Hogenboom LAP, Liem AKD. 2001. Dioxin and dioxin-like PCBs in foodstuffs: occurrence and dietary intake in The Netherlands at the end of the 20th century. RIVM report 639102022 and RIKILT report 2001.003.

Ghidini S, Zanardi E, Battaglia A, Varisco G, Ferretti E, Campanini G, Chizzolini R. 2005. Comparison of contaminant and residue levels in organic and conventional milk and meat products from northern Italy. Food Addit Contam. Jan;22(1):9-14.

Gilman A, Newhook R, Birmingham B, 1995. Update of health and environment risk management activities in Canada. Organohalogen Compounds, 26: 471-474.

Gunderson EL. 1988. FDA Total Diet Study, April 1982-April 1984, dietary intakes of pesticides, selected elements, and other chemicals. JAOAC 7(6): 1200-1209.

Hansen LG. 1998. Stepping backward to improve assessment of PCB congener toxicities. Environ Health Perspect Suppl 106(1):171-189. 
Himberg K, Hallikainen A, Louekari K. 1993. Intake of polychlorinated biphenyls (PCB) from the Finnish diet. Z Lebensm Unters Forsch. Feb;196(2):12630.

Huwe JK, Larsen GL. 2005. Polychlorinated dioxins, furans, and biphenyls, and polybrominated diphenyl ethers in a U.S. meat market basket and estimates of dietary intake. Environ Sci Technol. Aug 1;39(15):5606-11.

IARC (International Agency for Research on Cancer). 1987. IARC Monographs on the Evaluation of Carcinogenic Risks to Humans, Supplement 7, Overall Evaluations of Carcinogenicity: An Updating of IARC Monographs Volumes 1-42. Lyon, France.

Ishikawa Y, Falandysz J, Noma Y, Sakai S. 2005. Chlorobiphenyl constituents of Aroclor 1268, Chlorofen, Clophen T 64, KC-600, and KC-1000 technical formulations. J Environ Sci Health A Tox Hazard Subst Environ Eng. 2005;40(12):2171-87.

Joint FAO/WHO Expert Committee on Food Additives. 2001. Summary and Conclusions of the Fifty-seventh Meeting.

Juan CY, Thomas GO, Sweetman AJ, Jones KC. 2002. An input-output balance study for PCBs in humans. Environ Int. Jul;28(3):203-14.

Kannan K, Tanabe S, Williams RJ, Tatsukawa R. 1994. Persistant organochlorine residues in foodstuffs from Australia, Papua New Guinea and the Solomon islands: contamination levels and human dietary exposure. The Science of the Total Environment 153: 29-49.

Kannan K, Tanabe S, Quynh HT, Hue ND and Tatsukawa R. 1992a. Residue pattern and dietary intake of persistent organochlorine compounds in foodstuffs from Vietnam. Archives of Environmental Contamination and Toxicology 22, 367-374.

Kannan K, Tanabe S, Ramesh A, Subramanian A and Tatsukawa R. 1992b. Persistent organochlorine residues in foodstuffs from India and their implications on human dietary exposure. Journal of Agriculture and Food Chemistry 40, 518-524.

Koizumi A, Yoshinaga T, Harada K, Inoue K, Morikawa A, Muroi J, Inoue S, Eslami B, Fujii S, Fujimine Y, Hachiya N, Koda S, Kusaka Y, Murata K, 
Nakatsuka H, Omae K, Saito N, Shimbo S, Takenaka K, Takeshita T, Todoriki H, Wada Y, Watanabe T, Ikeda M. 2005. Assessment of human exposure to polychlorinated biphenyls and polybrominated diphenyl ethers in Japan using archived samples from the early 1980s and mid1990s. Environ Res. Sep;99(1):31-9. Epub 2005 Jan 22.

Lazaro R, Herrera A, Conchello MP, Arino AA, Bayarri S, Yague C, Peiro JM. 1999. Levels of selected polychlorinated biphenyl congeners in total diet samples from Aragon, Spain. J Food Prot. Sep;62(9):1054-8.

Liem AKD, Fürst P. and Rappe C. 2000. Exposure of populations to dioxins and related compounds. Food Addit Contam. 2000 Apr;17(4):241-59.

Matsumoto H, Murakami Y, Kuwabara K, et al. 1987. Average daily intake of pesticides and polychlorinated biphenyls in total diet samples in Osaka, Japan. Bull Environ Contam Toxicol 38:954-958.

McFarland VA, Clarke JU. 1989. Environmental occurrence, abundance, and potential toxicity of polychlorinated biphenyl congeners: considerations for a congener-specific analysis. Environ. Health Perspect. 81: 225-239.

Mes J, Newsome WH, Conacher HBS. 1989. Determination of some specific isomers of polychlorinated biphenyl congeners in fatty foods of the Canadian diet. Food Additives and Contaminants 6: 365-75.

Moilanen R, Pyysalo $\mathrm{H}$ and Kumpulainen J 1986. Average total dietary intakes of organochlorine compounds from the Finnish diet. Zeitschrift für Lebensmittel-Untersuchung und -Forschung 182: 484-488.

Newsome WH, Davies DJ, Sun WF. 1998. Residues of polychlorinated biphenyls (PCB) in fatty foods of the Canadian diet. Food Additives and Contaminants, 15(1):19-29.

Pearson RF, Hornbuckle KC, Eisenreich SJ, et al. 1996. PCBs in Lake Michigan water revisited. Environ Sci Technol 30(5):1429-1436.

Peattie ME, Buss DH, Lindsay DG and Smart GQ. 1983. Reorganisation of the British Total Diet Study for monitoring food constituents from 1981. Food and Chemical Toxicology. 21, 503-507. 
Pennington JAT and Gunderson EL. 1987. History of the Food and Drug Administration's Total Diet Study-1961 to 1987, J. Assoc. Off. Anal. Chem. 70: 772-782.

Pennington JAT, Capar SG, Parfitt CH, and Edwards CW. 1996. History of the Food and Drug Administration's Total Diet Study (Part II), 1987-1993, J. AOAC Int. 79(1): 163-170.

Safe S. 1990. Polychlorinated biphenyls (PCBs), dibenzo-p-dioxins (PCDDs), dibenzofurans (PCDFs), and related compounds: environmental and mechanistic consideration which support the development of toxic equivalency factors (TEFs). Crit. Rev. Toxicol. 21(1):51-88.

Schecter A, Cramer P, Boggess K, Stanley J, Olson JR. 1997. Levels of dioxins, dibenzofurans, PCB and DDE congeners in pooled food samples collected in 1995 at supermarkets across the United States. Chemosphere 34: 1437-47.

Tanabe S, Kannan K, Tabucanon MS, Siriwong C, Ambe Y, Tatsukawa R. 1991. Organochlorine pesticide and polychlorinated biphenyl residues in foodstuffs from Bangkok, Thailand. Environ Pollut. 72(3):191-203.

Tsutsumi T, Yanagi T, Munetomo $\mathrm{N}$ et al. 2001. Update of daily intake of PCDDs, PCDFs and dioxin-like PCBs from food in Japan. Chemosphere 45: 1129-1137,.

Turci R, Angeleri F, Minoia C. 2002. A rapid screening method for routine congener-specific analysis of polychlorinated biphenyls in human serum by high-resolution gas chromatography with mass spectrometric detection. Rapid Communications in Mass Spectrometry 16(20): 19571964.

Turci R, Mariani G, Marinaccio A, Balducci C, Bettinelli M, Fanelli R, Nichetti S, Minoia C. 2004. Critical evaluation of a high-throughput analytical method for PCBs in human serum: which detector for the establishment of the reference values? Rapid Communications in Mass Spectrometry 18:421434. 
Turrini A, Saba A, Perrone D, Cialfa E, D'Amicis A. 2001. Food consumption patterns in Italy: the INN-CA Study 1994-1996. Eur J Clin Nutr. Jul;55(7):571-588.

US Environmental Protection Agency. 1996. Report on peer review workshop on PCBs: cancer-dose response assessment and application to environmental mixtures. Washington, DC, National Center for Environmental Assessment.

US Environmental Protection Agency. 1999. Office of Pesticide Programs. Health Effects Division. "Classification of Food Forms With Respect to Level of Blending." HED Standard Operating Procedure 99.6 (8/20/99) August 20.

van der Berg M, Birnbaum L, Bosveld ATC, Brunstrom B, Cook P, Feeley M, Giesy JP, Hanberg A, Hasegawa R, Kennedy SW, Kubiak T, Larsen JC, Van Leeuwen FX, Liem AK, Nolt C, Peterson RE, Poellinger L, Safe S, Schrenk D, Tillitt D, Tysklind M, Younes M, Waern F, Zacharewski T. 1998. Toxic equivalency factors (TEFs) for PCBs, PCDDs, PCDFs for humans and wildlife. Environ. Health Perspect. 106:775-792.

van Leeuwen FXR, Younes M. 1998. WHO revises the Tolerable Daily Intake (TDI) for dioxins. Organohalogen Compounds 38:295-298.

van Leeuwen FXR and Younes, M eds. 2000. Assessment of the health risk of dioxins: re-evaluation of the tolerable daily intake (TDI). Organized by WHO European Centre for Enviornment and Health and International Programme on Chemical Safety. Food Additives and Contaminants. 17: 233-369.

WHO (World Health Organization). 1993. Polychlorinated biphenyls and terphenyls. Geneva: WHO, Environmental Health Criteria 140, second ed.

WHO (World Health Organization). 1998. Draft executive summary. Assessment of the health risk of dioxins: re-evaluation of the tolerable daily intake (TDI). WHO Consultation Meeting, May 25-29 1998, Geneva, Switzerland. 
Zabik ME, Booren A, Zabik MJ, Welch R, Humphrey H. 1996. Pesticide residues, PCBs and PAHs in baked, charbroiled, salt boiled and smoked Great Lakes lake trout. Food Chem 55(3):231-239.

Zuccato E, Calvarese S, Mariani G, Mangiapan S, Grasso P, Guzzi A, Fanelli R. 1999. Level, sources and toxicity of polychlorinated biphenyls in the Italian diet. Chemosphere 38: 2753-2765. 
Table I. Detailed list of the foodstuffs collected at the university cafeteria and purchased at a supermarket, located in Pavia, Northern Italy.

\begin{tabular}{|c|c|c|}
\hline Sample & $\begin{array}{l}N^{\circ} \text { of samples } \\
\text { collected at } \\
\text { the cafeteria }\end{array}$ & $\begin{array}{l}\mathrm{N}^{\circ} \text { of samples } \\
\text { purchased at } \\
\text { the supermarket }\end{array}$ \\
\hline $\begin{array}{l}\text { Cereals and tubers } \\
\text { Bread } \\
\text { Pizza margherita } \\
\text { Pizza (würstel, ham, onions) } \\
\text { Crackers, bread sticks } \\
\text { Cornflakes } \\
\text { Polenta (thick corn mush) } \\
\text { Pasta with eggplants and peppers } \\
\text { Pasta with tomato and ricotta cheese } \\
\text { Pasta with tomato } \\
\text { Pasta amatriciana } \\
\text { Pasta with cream,peas,carrots, potatoes } \\
\text { Pasta with zucchini, eggplants, peppers } \\
\text { Pasta with tuna and tomato } \\
\text { Pasta with gravy } \\
\text { Pasta with tomato and rucola } \\
\text { Pasta with cream and gorgonzola } \\
\text { Pasta with seafoods } \\
\text { Pasta with cauliflowers } \\
\text { Risotto with spinach } \\
\text { Risotto with pork meat } \\
\text { Risotto with peas, carrots, and potatoes } \\
\text { Risotto with mushrooms } \\
\text { Risotto with peas } \\
\text { Risotto with artichokes } \\
\text { Fried rice balls } \\
\text { Potato damplings with gravy } \\
\text { Potato damplings with cream and } \\
\text { gorgonzola } \\
\text { Boiled potatoes } \\
\text { Fried potatoes }\end{array}$ & $\begin{array}{c}2 \\
1 \\
2 \\
9 \\
2 \\
1 \\
3 \\
1 \\
2 \\
1 \\
1 \\
1 \\
1 \\
2 \\
1 \\
2 \\
1 \\
1 \\
1 \\
1 \\
1 \\
1 \\
10 \\
9\end{array}$ & $\begin{array}{l}1 \\
1\end{array}$ \\
\hline $\begin{array}{l}\text { Meat and meat products, fish and fish } \\
\text { products, eggs, legumes } \\
\text { Beef steak } \\
\text { Beef shank } \\
\text { Stew (beef, peas, potatoes) } \\
\text { Meat balls (pork, poultry, eggs) } \\
\text { Pepper stuffed with minced meats } \\
\text { Pork cutlet }\end{array}$ & $\begin{array}{l}4 \\
1 \\
2 \\
3 \\
2 \\
1\end{array}$ & \\
\hline
\end{tabular}




\begin{tabular}{|c|c|c|}
\hline Sample & $\begin{array}{l}N^{\circ} \text { of samples } \\
\text { collected at } \\
\text { the cafeteria }\end{array}$ & $\begin{array}{l}\mathrm{N}^{\circ} \text { of samples } \\
\text { purchased at } \\
\text { the supermarket }\end{array}$ \\
\hline $\begin{array}{l}\text { Pork cutlet with mushrooms } \\
\text { Roasted turkey } \\
\text { Grilled turkey breast } \\
\text { Roasted chicken (wing, breast) } \\
\text { Breaded chicken breast } \\
\text { Breaded hamburger (pork, turkey) } \\
\text { Hamburger (pork and turkey) } \\
\text { Tripe } \\
\text { Parma ham } \\
\text { Ham steak } \\
\text { Dried beef } \\
\text { Speck ham } \\
\text { Breaded cod fillets } \\
\text { Fried cod sticks } \\
\text { Shrimps } \\
\text { Flounder } \\
\text { Tuna fish in olive oil } \\
\text { Hard-boiled eggs } \\
\text { Omelette with spinach and ricotta } \\
\text { cheese } \\
\text { Green beans } \\
\text { Boiled peas } \\
\text { Peas with tomato sauce } \\
\text { Beans (French, haricot, white) } \\
\text { Green olives }\end{array}$ & $\begin{array}{c}1 \\
6 \\
1 \\
2 \\
2 \\
1 \\
3 \\
1 \\
4 \\
10 \\
4 \\
2 \\
2 \\
1\end{array}$ & $\begin{array}{l}1 \\
1 \\
1\end{array}$ \\
\hline $\begin{array}{l}\text { Milk and dairy products } \\
\text { Whole milk } \\
\text { Cream } \\
\text { Cheese (fontina, smoked provola, } \\
\text { asiago, taleggio, primo sale) } \\
\text { Cheese (mozzarella, philadelphia, } \\
\text { caprino) } \\
\text { Yogurt (apricot) } \\
\text { Yogurt (banana) } \\
\text { Yogurt (strawberry) } \\
\text { Yogurt (raspberry, } \\
\text { blackcurrant, blueberry) }\end{array}$ & $\begin{array}{c}10 \\
10 \\
1 \\
1 \\
1\end{array}$ & $\begin{array}{l}1 \\
1\end{array}$ \\
\hline $\begin{array}{l}\text { Vegetables and fruit } \\
\text { Boiled carrots } \\
\text { Green salad } \\
\text { Boiled cauliflowers }\end{array}$ & $\begin{array}{l}4 \\
7 \\
3\end{array}$ & \\
\hline
\end{tabular}




\begin{tabular}{|c|c|c|}
\hline Sample & $\begin{array}{l}\mathrm{N}^{\circ} \text { of samples } \\
\text { collected at } \\
\text { the cafeteria }\end{array}$ & $\begin{array}{l}\mathrm{N}^{\circ} \text { of samples } \\
\text { purchased at } \\
\text { the supermarket }\end{array}$ \\
\hline $\begin{array}{l}\text { Boiled beetroots } \\
\text { Boiled fennels } \\
\text { Boiled spinach } \\
\text { Brussels sprouts } \\
\text { Tomatoes salad } \\
\text { Mixed salad } \\
\text { Mixed big-salad (tuna fish, potatoes, } \\
\text { peas, carrots, olives, tomatoes, green } \\
\text { beans, corn, green salad) } \\
\text { Mayonnaise, peas, carrots, potatoes } \\
\text { Fruit (kiwi, peach, apple, banana) } \\
\text { Oranges, grapefruits, mandarin oranges) } \\
\text { Nuts, peanuts } \\
\text { Dried apricots }\end{array}$ & $\begin{array}{l}4 \\
5 \\
3 \\
3 \\
6 \\
3\end{array}$ & $\begin{array}{l}3 \\
2 \\
1\end{array}$ \\
\hline $\begin{array}{l}\text { Cakes and desserts } \\
\text { Creamy tiramisù } \\
\text { Chocolate pudding } \\
\text { Crème- caramel pudding } \\
\text { Vanilla pudding } \\
\text { Lemon ice-cream } \\
\text { Vanilla and chocolate ice-cream }\end{array}$ & $\begin{array}{l}1 \\
1 \\
1 \\
1 \\
1 \\
1\end{array}$ & \\
\hline $\begin{array}{l}\text { Beverages } \\
\text { Bottled mineral water } \\
\text { Bottled mineral water (sparkling) } \\
\text { Red wine } \\
\text { White wine } \\
\text { Beer } \\
\text { Cola flavored carbonated beverage } \\
\text { Orange flavored carbonated beverage } \\
\text { Lime flavored carbonated beverage }\end{array}$ & $\begin{array}{l}1 \\
1 \\
1 \\
1 \\
1 \\
1 \\
1 \\
1\end{array}$ & \\
\hline $\begin{array}{l}\text { Fats and oils } \\
\text { Olive oil } \\
\text { Seed oil } \\
\text { Butter } \\
\text { Margarine }\end{array}$ & & $\gamma$ \\
\hline TOTAL & 226 & 22 \\
\hline
\end{tabular}


Table Ila. Concentrations $(\mathrm{ng} / \mathrm{kg}$ ) of trichlorobiphenyls $(31,28)$ and tetrachlorobiphenyls $(52,49,47,44,74,70,66)$ in the foodstuffs collected from a cafeteria in Pavia ( $\mathrm{nd}=$ not detected, below the detection limit).

\begin{tabular}{|l|c|c|c|c|c|c|c|c|c|}
\hline FOOD HOMOGENIZED & \multicolumn{7}{|c|}{ CONGENER \# } \\
\cline { 2 - 7 } FOR ANALYSIS & $\mathbf{3 1}$ & $\mathbf{2 8}$ & $\mathbf{5 2}$ & $\mathbf{4 9}$ & $\mathbf{4 7}$ & $\mathbf{4 4}$ & $\mathbf{7 4}$ & $\mathbf{7 0}$ & $\mathbf{6 6}$ \\
\hline Bread & nd & 1.5 & nd & nd & nd & nd & nd & nd & nd \\
\hline Pizza margherita & nd & nd & nd & nd & 4.8 & nd & nd & nd & nd \\
\hline $\begin{array}{l}\text { Pizza (würstel, ham, } \\
\text { Onions) }\end{array}$ & 2.1 & nd & nd & nd & 6.3 & nd & 1.8 & nd & nd \\
\hline Crackers, bread sticks & nd & nd & nd & nd & nd & nd & nd & nd & nd \\
\hline Cornflakes & 5.3 & 12.4 & 28.8 & 7.4 & 13.8 & 13.9 & 6.3 & 22.5 & 11.8 \\
\hline $\begin{array}{l}\text { Polenta (thick corn } \\
\text { mush) }\end{array}$ & nd & nd & nd & nd & nd & nd & nd & nd & nd \\
\hline $\begin{array}{l}\text { Pasta with eggialant } \\
\text { sand peppers }\end{array}$ & 3.6 & 2.0 & 1.8 & nd & 4.2 & nd & nd & nd & nd \\
\hline $\begin{array}{l}\text { Pasta with tomato } \\
\text { and ricotta cheese }\end{array}$ & nd & nd & nd & nd & 1.6 & nd & nd & nd & nd \\
\hline Pasta with tomato & nd & nd & nd & nd & nd & nd & nd & nd & nd \\
\hline Pasta amatriciana & nd & nd & nd & nd & 1.2 & nd & nd & nd & nd \\
\hline $\begin{array}{l}\text { Pasta with cream, } \\
\text { peas, carrots, } \\
\text { potatoes }\end{array}$ & nd & nd & nd & nd & nd & nd & nd & nd & nd \\
\hline $\begin{array}{l}\text { Pasta with zucchini, } \\
\text { eggplants, peppers }\end{array}$ & nd & nd & nd & nd & nd & nd & nd & nd & nd \\
\hline $\begin{array}{l}\text { Pasta with tuna and } \\
\text { tomatoes }\end{array}$ & 6.6 & nd & 11.6 & 7.7 & 13.7 & 4.9 & nd & nd & nd \\
\hline Pasta with gravy & nd & nd & nd & nd & nd & nd & nd & nd & nd \\
\hline $\begin{array}{l}\text { Pasta with tomatoes } \\
\text { and rucola }\end{array}$ & nd & nd & nd & nd & nd & nd & nd & nd & nd \\
\hline $\begin{array}{l}\text { Pasta with cream and } \\
\text { gorgonzola }\end{array}$ & nd & nd & nd & nd & nd & nd & nd & nd & nd \\
\hline $\begin{array}{l}\text { Pasta with seafood } \\
\text { Pasta with } \\
\text { cauliflowers }\end{array}$ & 21.0 & 15.3 & 12.3 & 13.2 & 16.8 & nd & 22.5 & 12.3 & nd \\
\hline $\begin{array}{l}\text { Potato damplings with } \\
\text { gravy }\end{array}$ & nd & nd & nd & nd & nd & nd & nd & nd & nd \\
\hline
\end{tabular}




\begin{tabular}{|c|c|c|c|c|c|c|c|c|c|}
\hline \multirow{2}{*}{$\begin{array}{l}\text { FOOD HOMOGENIZED } \\
\text { FOR ANALYSIS }\end{array}$} & \multicolumn{9}{|c|}{ CONGENER \# } \\
\hline & 31 & 28 & 52 & 49 & 47 & 44 & 74 & 70 & 66 \\
\hline $\begin{array}{l}\text { Potato damplings with } \\
\text { cream and } \\
\text { gorgonzola }\end{array}$ & nd & nd & nd & nd & nd & nd & nd & nd & nd \\
\hline Risotto with spinach & nd & nd & nd & nd & nd & nd & nd & nd & nd \\
\hline Risotto with pork meat & 27.0 & nd & 13.0 & 19.0 & 61.0 & nd & nd & nd & nd \\
\hline $\begin{array}{l}\text { Risotto with peas, } \\
\text { carrots and potatoes }\end{array}$ & 11.3 & nd & 4.7 & 4.7 & 1.8 & 2.1 & 4.7 & nd & nd \\
\hline $\begin{array}{l}\text { Risotto with } \\
\text { mushrooms }\end{array}$ & nd & nd & nd & nd & nd & nd & nd & nd & nd \\
\hline Risotto with peas & nd & nd & nd & nd & nd & nd & nd & nd & nd \\
\hline Risotto with artichokes & nd & nd & 3.4 & 2.9 & 3.1 & nd & nd & nd & nd \\
\hline Fried rice balls & nd & nd & 5.9 & nd & 6.7 & nd & nd & nd & nd \\
\hline Boiled potatoes & nd & 8.0 & nd & nd & 1.6 & nd & nd & nd & nd \\
\hline Fried potatoes & nd & 8.4 & nd & nd & 2.1 & nd & nd & nd & nd \\
\hline Potato puree & nd & nd & nd & nd & nd & nd & nd & nd & nd \\
\hline Beef steak & nd & 5.1 & nd & nd & 3.2 & nd & nd & nd & nd \\
\hline $\begin{array}{l}\text { Pepper stuffed with } \\
\text { minced meats }\end{array}$ & nd & nd & nd & nd & nd & nd & nd & nd & nd \\
\hline $\begin{array}{l}\text { Meat balls (pork, } \\
\text { poultry, eggs) }\end{array}$ & nd & 1.2 & nd & nd & 5.1 & nd & nd & nd & nd \\
\hline $\begin{array}{l}\text { Stew (beef, peas, } \\
\text { potatoes) }\end{array}$ & nd & 8.2 & 11.3 & nd & 11.7 & 6.5 & 6.7 & nd & nd \\
\hline Beef shank & nd & 3.0 & 61.5 & nd & nd & nd & nd & nd & nd \\
\hline Pork cutlet & nd & 21 & nd & nd & nd & nd & nd & nd & nd \\
\hline $\begin{array}{l}\text { Pork cutlet with } \\
\text { mushrooms }\end{array}$ & nd & 20 & nd & nd & nd & nd & nd & nd & nd \\
\hline $\begin{array}{l}\text { Hamburger (pork and } \\
\text { turkey) }\end{array}$ & nd & 12.1 & 32.1 & nd & nd & nd & nd & nd & nd \\
\hline Roasted turkey & nd & nd & nd & nd & nd & nd & nd & nd & nd \\
\hline $\begin{array}{l}\text { Breaded chicken } \\
\text { breast }\end{array}$ & nd & nd & nd & nd & nd & nd & nd & nd & nd \\
\hline
\end{tabular}




\begin{tabular}{|c|c|c|c|c|c|c|c|c|c|}
\hline \multirow{2}{*}{$\begin{array}{l}\text { FOOD HOMOGENIZED } \\
\text { FOR ANALYSIS }\end{array}$} & \multicolumn{9}{|c|}{ CONGENER \# } \\
\hline & 31 & 28 & 52 & 49 & 47 & 44 & 74 & 70 & 66 \\
\hline $\begin{array}{l}\text { Roasted chicken } \\
\text { (wing, breast) }\end{array}$ & nd & 1.8 & nd & nd & nd & nd & nd & nd & nd \\
\hline $\begin{array}{l}\text { Breaded hamburger } \\
\text { (pork, turkey) }\end{array}$ & 58 & nd & nd & nd & 86 & nd & nd & nd & nd \\
\hline Grilled turkey breast & nd & nd & nd & nd & 21.3 & nd & nd & nd & nd \\
\hline Parma ham & nd & nd & nd & nd & nd & nd & nd & nd & nd \\
\hline Ham steak & nd & nd & 6.3 & nd & 12 & nd & nd & nd & nd \\
\hline Dried beef & 2.1 & nd & nd & nd & 14.7 & nd & nd & nd & nd \\
\hline Speck ham & nd & 1.3 & nd & nd & 21 & nd & nd & nd & nd \\
\hline Breaded cod fillets & nd & nd & 67 & nd & 94 & nd & nd & nd & nd \\
\hline Fried cod sticks & 221 & nd & 141 & nd & 131 & nd & nd & nd & nd \\
\hline Shrimps & 39 & nd & 20 & 19 & 78 & nd & nd & nd & nd \\
\hline Flounder & nd & nd & 131 & nd & 47 & 97 & nd & nd & nd \\
\hline Tuna fish in olive oil & nd & nd & 445 & nd & 1151 & nd & nd & nd & nd \\
\hline Hard boiled eggs & 73 & nd & 24 & 32 & 83 & nd & 29 & nd & nd \\
\hline $\begin{array}{l}\text { Omelette with spinach } \\
\text { and ricotta cheese }\end{array}$ & 85 & nd & 38 & 36 & 98 & nd & 40 & nd & nd \\
\hline Boiled carrots & nd & nd & nd & nd & nd & nd & nd & nd & nd \\
\hline Green salad & nd & nd & nd & nd & nd & nd & nd & nd & nd \\
\hline Boiled cauliflowers & 11 & 25 & 10 & nd & nd & nd & nd & nd & nd \\
\hline Boiled beetroots & 7.1 & 46.4 & 17.3 & nd & nd & nd & nd & nd & nd \\
\hline Boiled fennels & 19.9 & 24.8 & 19.8 & 7.6 & 8.6 & 12.6 & 9.1 & 20.2 & 19.2 \\
\hline Boiled spinach & 2.1 & 12.9 & 14.6 & nd & 14.8 & 28.3 & 12.5 & nd & nd \\
\hline Brussels sprouts & nd & nd & nd & nd & nd & nd & nd & nd & nd \\
\hline
\end{tabular}




\begin{tabular}{|c|c|c|c|c|c|c|c|c|c|}
\hline \multirow{2}{*}{$\begin{array}{l}\text { FOOD HOMOGENIZED } \\
\text { FOR ANALYSIS }\end{array}$} & \multicolumn{9}{|c|}{ CONGENER \# } \\
\hline & 31 & 28 & 52 & 49 & 47 & 44 & 74 & 70 & 66 \\
\hline Mixed salad & nd & nd & nd & 1.3 & 1.4 & 4.0 & nd & nd & nd \\
\hline Tomatoes salad & nd & nd & nd & nd & nd & nd & nd & nd & nd \\
\hline Green beans & nd & nd & nd & nd & nd & nd & nd & nd & nd \\
\hline $\begin{array}{l}\text { Peas with tomato } \\
\text { sauce }\end{array}$ & nd & nd & nd & nd & nd & nd & nd & nd & nd \\
\hline Boiled peas & nd & nd & nd & nd & nd & nd & nd & nd & nd \\
\hline $\begin{array}{l}\text { Beans (French, } \\
\text { haricot, white) }\end{array}$ & nd & nd & nd & nd & nd & nd & nd & nd & nd \\
\hline Whole milk & nd & nd & nd & nd & 2.93 & nd & nd & nd & nd \\
\hline Yogurt (c & nd & 8.5 & nd & nd & 9.9 & nd & nd & nd & nd \\
\hline Yogurt (banana) & nd & nd & nd & nd & nd & nd & nd & nd & nd \\
\hline Yogurt (strawberry) & 7.3 & 10.1 & 10.4 & nd & 9.4 & nd & nd & nd & nd \\
\hline $\begin{array}{l}\text { Yogurt (ra } \\
\text { blueberry }\end{array}$ & nd & 10.4 & 12.0 & nd & 9.9 & nd & nd & nd & nd \\
\hline Cheese & 4.8 & nd & nd & nd & 18 & nd & nd & nd & nd \\
\hline Chocolate pudding & nd & nd & 0.8 & nd & 1.1 & nd & nd & nd & nd \\
\hline $\begin{array}{l}\text { Crème caramel } \\
\text { pudding }\end{array}$ & nd & nd & 1.4 & nd & 3.8 & nd & 1.0 & 1.4 & 1.1 \\
\hline Creamy tiramisu & nd & nd & nd & nd & nd & nd & nd & nd & nd \\
\hline Vanilla pudding & nd & nd & 1.3 & nd & 0.8 & nd & nd & nd & nd \\
\hline Lemon ice-cream & nd & nd & 1.2 & nd & 0.91 & nd & nd & nd & nd \\
\hline $\begin{array}{l}\text { Vanilla and } \\
\text { chocolate ice-cream }\end{array}$ & nd & nd & 1.4 & nd & nd & nd & nd & nd & nd \\
\hline $\begin{array}{l}\text { Oranges, grapefruits, } \\
\text { mandarin oranges }\end{array}$ & 1.7 & nd & nd & nd & 2.2 & nd & nd & nd & nd \\
\hline $\begin{array}{l}\text { Fruit (kiwi, peach, } \\
\text { apple, banana) }\end{array}$ & 4.7 & 7.7 & 3.1 & nd & 4.0 & nd & 2.6 & nd & nd \\
\hline Nuts, peanuts & nd & nd & nd & nd & nd & nd & nd & nd & nd \\
\hline
\end{tabular}




\begin{tabular}{|l|c|c|c|c|c|c|c|c|c|}
\hline FOOD HOMOGENIZED & \multicolumn{9}{|c|}{ CONGENER \# } \\
\cline { 2 - 11 } FOR ANALYSIS & $\mathbf{3 1}$ & $\mathbf{2 8}$ & $\mathbf{5 2}$ & $\mathbf{4 9}$ & $\mathbf{4 7}$ & $\mathbf{4 4}$ & $\mathbf{7 4}$ & $\mathbf{7 0}$ & $\mathbf{6 6}$ \\
\hline Dried apricots & nd & nd & nd & nd & 4.2 & nd & 7.6 & nd & nd \\
\hline Cola flavored bev. & 0.71 & nd & 0.33 & 0.61 & 3.3 & nd & 1.3 & nd & nd \\
\hline Orange flavored bev. & 0.55 & nd & 0.93 & nd & 4.7 & nd & 1.9 & nd & nd \\
\hline Lime flavored bev. & nd & nd & 0.50 & nd & 3.2 & nd & 1.0 & nd & nd \\
\hline Beer & nd & nd & 0.35 & 0.68 & 2.9 & 1.1 & nd & nd & nd \\
\hline Red wine & nd & nd & 0.63 & nd & 3.7 & nd & 1.5 & nd & nd \\
\hline White wine & nd & nd & 0.50 & nd & 0.33 & nd & nd & nd & nd \\
\hline Bottled mineral water & nd & nd & nd & nd & nd & nd & nd & nd & nd \\
\hline
\end{tabular}


Table Illb. Concentrations (ng/kg) of pentachlorobiphenyls (101, 99, 110 , $118,105)$ and hexachlorobiphenyls $(153,138,156)$ in the foodstuffs collected from a cafeteria in Pavia (nd $=$ not detected, below the detection limit).

\begin{tabular}{|l|c|c|c|c|c|c|c|c|}
\hline FOOD HOMOGENIZED & \multicolumn{7}{|c|}{ CONGENER \# } \\
\cline { 2 - 9 } & 101 & 99 & 110 & 118 & 105 & 153 & 138 & 156 \\
\hline Bread & nd & nd & nd & nd & nd & nd & nd & nd \\
\hline Pizza margherita & nd & nd & nd & nd & nd & 2.7 & nd & nd \\
\hline $\begin{array}{l}\text { Pizza (würstel, ham, } \\
\text { onions) }\end{array}$ & nd & nd & nd & nd & nd & 6.7 & nd & nd \\
\hline Crackers, bread sticks & 28 & nd & nd & nd & nd & 7.5 & nd & nd \\
\hline Cornflakes & nd & nd & nd & nd & nd & 12.5 & 12.1 & nd \\
\hline $\begin{array}{l}\text { Polenta (thick corn } \\
\text { mush) }\end{array}$ & nd & nd & nd & nd & nd & nd & nd & nd \\
\hline $\begin{array}{l}\text { Pasta with eggplants } \\
\text { and peppers }\end{array}$ & nd & nd & nd & nd & nd & nd & 4.3 & nd \\
\hline $\begin{array}{l}\text { Pasta with tomato } \\
\text { and ricotta cheese }\end{array}$ & nd & nd & nd & nd & nd & 1.3 & nd & nd \\
\hline Pasta with tomato & nd & nd & nd & nd & nd & 1.6 & nd & nd \\
\hline Pasta amatriciana & nd & nd & nd & nd & nd & 4.6 & 1.2 & nd \\
\hline $\begin{array}{l}\text { Pasta with cream, peas, } \\
\text { carrots, potatoes }\end{array}$ & nd & nd & nd & nd & nd & 42.5 & 57.5 & nd \\
\hline $\begin{array}{l}\text { Pasta with zucchini, } \\
\text { eggplants, peppers }\end{array}$ & nd & nd & nd & nd & nd & nd & nd & nd \\
\hline $\begin{array}{l}\text { Pasta with tuna and } \\
\text { tomato }\end{array}$ & 19.1 & nd & nd & nd & nd & 167 & 168 & nd \\
\hline Pasta with gravy & nd & nd & nd & nd & nd & nd & 11.5 & nd \\
\hline $\begin{array}{l}\text { Pasta with tomato } \\
\text { and rucola }\end{array}$ & nd & nd & nd & nd & nd & nd & nd & nd \\
\hline $\begin{array}{l}\text { Pasta with cream and } \\
\text { gorgonzola }\end{array}$ & nd & nd & nd & nd & nd & 0.17 & nd & nd \\
\hline Pasta with seafood & 19.3 & nd & nd & 96.5 & 58.3 & 159 & 164 & 75.6 \\
\hline Pasta with cauliflowers & 7.4 & nd & nd & nd & nd & 18 & 22 & nd \\
\hline gravato damplings with & nd & nd & nd & nd & nd & 2.2 & nd & nd \\
\hline
\end{tabular}




\begin{tabular}{|c|c|c|c|c|c|c|c|c|}
\hline \multirow{2}{*}{$\begin{array}{l}\text { FOOD HOMOGENIZED } \\
\text { FOR ANALYSIS }\end{array}$} & \multicolumn{8}{|c|}{ CONGENER \# } \\
\hline & 101 & 99 & 110 & 118 & 105 & 153 & 138 & 156 \\
\hline $\begin{array}{l}\text { Potato damplings with } \\
\text { cream and } \\
\text { gorgonzola }\end{array}$ & nd & nd & nd & nd & nd & 0.12 & nd & nd \\
\hline Risotto with spinach & nd & nd & nd & nd & nd & nd & nd & nd \\
\hline Risotto with pork meat & 63 & nd & nd & nd & nd & 36 & 44 & nd \\
\hline $\begin{array}{l}\text { Risotto with peas, } \\
\text { carrots and potatoes }\end{array}$ & 9.3 & nd & nd & nd & nd & 6.8 & 7.0 & nd \\
\hline $\begin{array}{l}\text { Risotto with } \\
\text { mushrooms }\end{array}$ & nd & nd & nd & nd & nd & nd & nd & nd \\
\hline Risotto with peas & nd & nd & nd & nd & nd & nd & nd & nd \\
\hline Risotto with artichokes & 6.9 & nd & nd & nd & nd & 3.7 & 2.1 & nd \\
\hline Fried rice balls & 23 & 3.8 & 12 & nd & nd & 15 & 19 & nd \\
\hline Boiled potatoes & nd & nd & nd & nd & nd & nd & nd & nd \\
\hline Fried potatoes & nd & nd & nd & nd & nd & nd & nd & nd \\
\hline Potato puree & nd & nd & nd & nd & nd & nd & nd & nd \\
\hline Beef steak & 5.2 & nd & nd & nd & nd & 2.9 & 3.6 & nd \\
\hline $\begin{array}{l}\text { Pepper stuffed with } \\
\text { minced meats }\end{array}$ & nd & nd & nd & nd & nd & 50 & 72 & nd \\
\hline $\begin{array}{l}\text { Meat balls (pork, } \\
\text { poultry, eggs) }\end{array}$ & nd & nd & nd & nd & nd & 21 & 19 & nd \\
\hline $\begin{array}{l}\text { Stew (beef, peas, } \\
\text { potatoes) }\end{array}$ & 11 & nd & nd & nd & nd & 15 & 15 & nd \\
\hline Beef shank & 9.7 & nd & nd & nd & nd & 31 & 51 & nd \\
\hline Pork cutlet & 6.3 & nd & nd & 3.1 & nd & 6.1 & 13 & nd \\
\hline $\begin{array}{l}\text { Pork cutlet with } \\
\text { mushrooms }\end{array}$ & 5.4 & nd & nd & 2.5 & nd & 10 & 10 & nd \\
\hline $\begin{array}{l}\text { Hamburger (pork and } \\
\text { turkey) }\end{array}$ & 131 & nd & nd & nd & nd & 211 & 204 & nd \\
\hline Roasted turkey & nd & nd & nd & nd & nd & 47 & 31 & nd \\
\hline $\begin{array}{l}\text { Breaded chicken } \\
\text { breast }\end{array}$ & nd & nd & nd & nd & nd & 59 & 20 & nd \\
\hline
\end{tabular}




\begin{tabular}{|c|c|c|c|c|c|c|c|c|}
\hline \multirow{2}{*}{$\begin{array}{l}\text { FOOD HOMOGENIZED } \\
\text { FOR ANALYSIS }\end{array}$} & \multicolumn{8}{|c|}{ CONGENER \# } \\
\hline & 101 & 99 & 110 & 118 & 105 & 153 & 138 & 156 \\
\hline $\begin{array}{l}\text { Roasted chicken } \\
\text { (wing, breast) }\end{array}$ & nd & nd & nd & nd & nd & 31 & 10 & nd \\
\hline $\begin{array}{l}\text { Breaded hamburger } \\
\text { (pork, turkey) }\end{array}$ & 48 & nd & nd & nd & nd & 54 & nd & nd \\
\hline Grilled turkey breast & nd & nd & nd & nd & nd & 21 & 26 & nd \\
\hline Parma ham & nd & nd & nd & nd & nd & 26 & 33 & nd \\
\hline Ham steak & 14 & nd & nd & nd & nd & 16 & 11 & nd \\
\hline Dried beef & 1.5 & nd & nd & nd & nd & 36 & 46 & nd \\
\hline Speck ham & 16 & nd & nd & nd & nd & 9.2 & 12.3 & nd \\
\hline Breaded cod fillets & 156 & nd & 184 & nd & nd & 77 & 66 & nd \\
\hline Fried cod sticks & 1256 & nd & 350 & nd & nd & 260 & 140 & nd \\
\hline Shrimps & nd & nd & nd & nd & nd & 57 & 93 & nd \\
\hline Flounder & nd & nd & nd & nd & nd & 620 & 410 & nd \\
\hline Tuna fish in olive oil & nd & nd & nd & nd & nd & 89 & nd & nd \\
\hline Hard boiled eggs & 87 & nd & nd & nd & nd & 140 & 131 & nd \\
\hline $\begin{array}{l}\text { Omelette with } \\
\text { spinach and ricotta } \\
\text { cheese }\end{array}$ & 125 & nd & nd & nd & nd & 179 & 148 & nd \\
\hline Boiled carrots & nd & nd & nd & nd & nd & nd & nd & nd \\
\hline Green salad & nd & nd & nd & nd & nd & nd & nd & nd \\
\hline Boiled cauliflowers & nd & nd & nd & nd & nd & 3.4 & 3.2 & nd \\
\hline Boiled beetroots & 59.7 & nd & nd & nd & nd & 87 & 81 & 70.2 \\
\hline Boiled fennels & 50.0 & nd & 46.3 & nd & nd & 117 & 99 & 30.1 \\
\hline Boiled spinach & 10.9 & nd & nd & nd & nd & 14.7 & 13.9 & nd \\
\hline Brussels sprouts & nd & nd & nd & nd & nd & nd & nd & nd \\
\hline
\end{tabular}




\begin{tabular}{|c|c|c|c|c|c|c|c|c|}
\hline \multirow{2}{*}{$\begin{array}{l}\text { FOOD HOMOGENIZED } \\
\text { FOR ANALYSIS }\end{array}$} & \multicolumn{8}{|c|}{ CONGENER \# } \\
\hline & 101 & 99 & 110 & 118 & 105 & 153 & 138 & 156 \\
\hline Mixed salad & 5.8 & nd & nd & nd & nd & 2.7 & 3.9 & nd \\
\hline Tomatoes salad & nd & nd & nd & nd & nd & nd & nd & nd \\
\hline Green beans & nd & nd & nd & nd & nd & nd & nd & nd \\
\hline $\begin{array}{l}\text { Peas with tomato } \\
\text { sauce }\end{array}$ & nd & nd & nd & nd & nd & nd & nd & nd \\
\hline Boiled peas & nd & nd & nd & nd & nd & nd & nd & nd \\
\hline $\begin{array}{l}\text { Beans (French, } \\
\text { haricot, white) }\end{array}$ & nd & nd & nd & nd & nd & nd & nd & nd \\
\hline Whole milk & 0.60 & nd & nd & nd & nd & 1.5 & 1.6 & nd \\
\hline Yogurt (apricot) & 28.9 & nd & nd & nd & nd & 22.9 & 26.2 & nd \\
\hline Yogurt (banana) & 22.6 & nd & nd & nd & nd & nd & nd & nd \\
\hline Yogurt (strawberry) & 55.5 & nd & nd & nd & nd & 15.8 & 14.4 & nd \\
\hline $\begin{array}{l}\text { Yogurt (raspberry, } \\
\text { blackcurrant, } \\
\text { blueberry) }\end{array}$ & 63.4 & nd & nd & nd & nd & 25.5 & 22.6 & 4.3 \\
\hline Cheese & 11.5 & nd & nd & nd & nd & 18.5 & 25 & nd \\
\hline Chocolate pudding & nd & nd & nd & nd & nd & 1.6 & 1.8 & nd \\
\hline $\begin{array}{l}\text { Crème caramel } \\
\text { pudding }\end{array}$ & nd & nd & nd & nd & nd & 1.2 & 1.3 & nd \\
\hline Creamy tiramisu & nd & nd & nd & nd & nd & nd & nd & nd \\
\hline Vanilla pudding & nd & nd & nd & nd & nd & 3.9 & 2.9 & nd \\
\hline Lemon ice-cream & 3.6 & nd & nd & nd & nd & 1.2 & 1.4 & nd \\
\hline $\begin{array}{l}\text { Vanilla and chocolate } \\
\text { ice-cream }\end{array}$ & nd & nd & nd & nd & nd & 1.03 & 1.2 & nd \\
\hline $\begin{array}{l}\text { Oranges, grapefruits, } \\
\text { mandarin oranges }\end{array}$ & nd & nd & nd & nd & nd & 3.4 & 3.9 & nd \\
\hline $\begin{array}{l}\text { Fruit (kiwi, peach, } \\
\text { apple, banana) }\end{array}$ & nd & nd & nd & nd & nd & 1.2 & 1.8 & nd \\
\hline Nuts, peanuts & nd & nd & nd & nd & nd & nd & nd & nd \\
\hline
\end{tabular}




\begin{tabular}{|l|c|c|c|c|c|c|c|c|}
\hline FOOD HOMOGENIZED & \multicolumn{7}{|c|}{ CONGENER \# } \\
\cline { 2 - 9 } FOR ANALYSIS & 101 & 99 & 110 & 118 & 105 & 153 & 138 & 156 \\
\hline Dried apricots & nd & nd & nd & nd & nd & 4.0 & 5.0 & nd \\
\hline Cola flavored bev. & nd & nd & nd & nd & nd & 1.2 & 0.42 & nd \\
\hline Orange flavored bev. & nd & nd & nd & nd & nd & nd & nd & nd \\
\hline Lime flavored bev. & nd & nd & nd & nd & nd & nd & nd & nd \\
\hline Beer & nd & nd & nd & nd & nd & nd & nd & nd \\
\hline Red wine & nd & nd & nd & nd & nd & nd & nd & nd \\
\hline White wine & nd & nd & nd & nd & nd & nd & nd & nd \\
\hline Bottled mineral water & nd & nd & nd & nd & nd & nd & nd & nd \\
\hline
\end{tabular}


Table Ilc. Concentrations (ng/kg) of heptachlorobiphenyls (187, 183, 180, 170) in the foodstuffs collected from a cafeteria in Pavia (nd $=$ not detected, below the detection limit).

\begin{tabular}{|l|c|c|c|c|}
\hline \multirow{2}{*}{$\begin{array}{l}\text { FOOD HOMOGENIZED } \\
\text { FOR ANALYSIS }\end{array}$} & \multicolumn{4}{|c|}{ CONGENER \# } \\
\cline { 2 - 5 } Bread & $\mathbf{1 8 7}$ & $\mathbf{1 8 3}$ & $\mathbf{1 8 0}$ & $\mathbf{1 7 0}$ \\
\hline Pizza margherita & nd & nd & nd \\
\hline Pizza (würstel, ham, onions) & nd & nd & 5.3 & nd \\
\hline Crackers, bread sticks & nd & nd & 1.5 & nd \\
\hline Cornflakes & nd & nd & 1.0 & nd \\
\hline Polenta (thick corn mush) & nd & nd & nd & nd \\
\hline $\begin{array}{l}\text { Pasta with eggplants and } \\
\text { peppers }\end{array}$ & nd & nd & 4.5 & nd \\
\hline $\begin{array}{l}\text { Pasta with tomato and ricotta } \\
\text { cheese }\end{array}$ & nd & nd & 1.3 & nd \\
\hline Pasta with tomato & nd & nd & 1.2 & nd \\
\hline Pasta amatriciana & nd & nd & 3.7 & nd \\
\hline $\begin{array}{l}\text { Pasta with cream, peas, carrots, } \\
\text { potatoes }\end{array}$ & nd & nd & 33 & nd \\
\hline $\begin{array}{l}\text { Pasta with zucchini, eggplants, } \\
\text { peppers }\end{array}$ & nd & nd & 1.1 & nd \\
\hline Pasta with tuna and tomato & nd & nd & 127 & 30 \\
\hline Pasta with gravy & nd & nd & 5.9 & nd \\
\hline Pasta with tomato and & nd & nd & 1.3 & nd \\
\hline $\begin{array}{l}\text { Pasta with cream and } \\
\text { gorgonzola }\end{array}$ & nd & nd & 0.80 & nd \\
\hline Pasta with seafood & nd & nd & 18.1 & nd \\
\hline Pasta with cauliflowers & nd & nd & 1.6 & nd \\
\hline Potato damplings with gravy & 152 & 46 \\
\hline
\end{tabular}




\begin{tabular}{|c|c|c|c|c|}
\hline \multirow{2}{*}{$\begin{array}{l}\text { FOOD HOMOGENIZED } \\
\text { FOR ANALYSIS }\end{array}$} & \multicolumn{4}{|c|}{ CONGENER \# } \\
\hline & 187 & 183 & 180 & 170 \\
\hline $\begin{array}{l}\text { Potato damplings with cream } \\
\text { and gorgonzola }\end{array}$ & nd & nd & 1.4 & nd \\
\hline Risotto with spinach & nd & nd & nd & nd \\
\hline Risotto with pork meat & nd & nd & 14 & nd \\
\hline $\begin{array}{l}\text { Risotto with peas, carrots and } \\
\text { potatoes }\end{array}$ & nd & nd & 1.2 & nd \\
\hline Risotto with mushrooms & nd & nd & nd & nd \\
\hline Risotto with peas & nd & nd & nd & nd \\
\hline Risotto with artichokes & nd & nd & 1.4 & nd \\
\hline Fried rice balls & nd & nd & 7.1 & 6.2 \\
\hline Boiled potatoes & nd & nd & nd & nd \\
\hline Fried potatoes & nd & nd & nd & nd \\
\hline Potato puree & nd & nd & nd & nd \\
\hline Beef steak & nd & nd & 6.7 & nd \\
\hline $\begin{array}{l}\text { Pepper stuffed with minced } \\
\text { meats }\end{array}$ & nd & nd & 14 & nd \\
\hline Meat balls (pork, poultry, eggs) & nd & nd & 13 & nd \\
\hline Stew (beef, peas, potatoes) & nd & nd & 12 & nd \\
\hline Beef shank & nd & nd & 24 & nd \\
\hline Pork cutlet & nd & nd & 11 & nd \\
\hline Pork cutlet with mushrooms & nd & nd & 9.8 & nd \\
\hline Hamburger (pork and turkey) & nd & nd & 220 & nd \\
\hline Roasted turkey & nd & nd & nd & nd \\
\hline Breaded chicken breast & nd & nd & nd & nd \\
\hline
\end{tabular}




\begin{tabular}{|c|c|c|c|c|}
\hline \multirow{2}{*}{$\begin{array}{l}\text { FOOD HOMOGENIZED } \\
\text { FOR ANALYSIS }\end{array}$} & \multicolumn{4}{|c|}{ CONGENER \# } \\
\hline & 187 & 183 & 180 & 170 \\
\hline $\begin{array}{l}\text { Roasted chicken (wing, } \\
\text { breast) }\end{array}$ & nd & nd & nd & nd \\
\hline $\begin{array}{l}\text { Breaded hamburger (pork, } \\
\text { turkey) }\end{array}$ & nd & nd & 14 & nd \\
\hline Grilled turkey breast & nd & nd & nd & nd \\
\hline Parma ham & nd & nd & nd & nd \\
\hline Ham steak & nd & nd & 6.7 & nd \\
\hline Dried beef & nd & nd & nd & nd \\
\hline Speck ham & nd & nd & 8.3 & 13 \\
\hline Breaded cod fillets & nd & nd & nd & nd \\
\hline Fried cod sticks & nd & nd & nd & nd \\
\hline Shrimps & 109 & nd & 29 & nd \\
\hline Flounder & 86 & 28 & 71 & nd \\
\hline Tuna fish in olive oil & nd & nd & nd & nd \\
\hline Hard boiled eggs & nd & nd & 46 & nd \\
\hline $\begin{array}{l}\text { Omelette with spinach and } \\
\text { ricotta cheese }\end{array}$ & 60 & 94 & 104 & nd \\
\hline Boiled carrots & nd & nd & nd & nd \\
\hline Green salad & nd & nd & nd & nd \\
\hline Boiled cauliflowers & nd & nd & 1.9 & nd \\
\hline Boiled beetroots & nd & nd & 94 & 18 \\
\hline Boiled fennels & 9.0 & 9.3 & 100 & 44 \\
\hline Boiled spinach & nd & nd & 4.3 & nd \\
\hline Brussels sprouts & nd & nd & nd & nd \\
\hline
\end{tabular}




\begin{tabular}{|c|c|c|c|c|}
\hline \multirow{2}{*}{$\begin{array}{l}\text { FOOD HOMOGENIZED } \\
\text { FOR ANALYSIS }\end{array}$} & \multicolumn{4}{|c|}{ CONGENER \# } \\
\hline & 187 & 183 & 180 & 170 \\
\hline Mixed salad & nd & nd & 2.3 & nd \\
\hline Tomatoes salad & nd & nd & nd & nd \\
\hline Green beans & nd & nd & nd & nd \\
\hline Peas with tomato sauce & nd & nd & nd & nd \\
\hline Boiled peas & nd & nd & nd & nd \\
\hline Beans (French, haricot, white) & nd & nd & nd & nd \\
\hline Whole milk & nd & nd & nd & nd \\
\hline Yogurt (apricot) & nd & nd & 14 & nd \\
\hline Yogurt (banana) & nd & nd & nd & nd \\
\hline Yogurt (strawberry) & nd & nd & 15 & nd \\
\hline $\begin{array}{l}\text { Yogurt (raspberry, } \\
\text { blackcurrant, blueberry) }\end{array}$ & nd & nd & 29 & nd \\
\hline Cheese & nd & nd & 41 & nd \\
\hline Chocolate pudding & nd & nd & 2.1 & nd \\
\hline Crème caramel pudding & nd & nd & nd & nd \\
\hline Creamy tiramisu & nd & nd & nd & nd \\
\hline Vanilla pudding & nd & nd & nd & nd \\
\hline Lemon ice-cream & nd & nd & nd & nd \\
\hline $\begin{array}{l}\text { Vanilla and chocolate } \\
\text { ice-cream }\end{array}$ & nd & nd & nd & nd \\
\hline $\begin{array}{l}\text { Oranges, grapefruits, } \\
\text { mandarin oranges }\end{array}$ & 2.1 & 2.1 & 3.8 & nd \\
\hline $\begin{array}{l}\text { Fruit (kiwi, peach, apple, } \\
\text { banana) }\end{array}$ & nd & nd & nd & nd \\
\hline Nuts, peanuts & nd & nd & nd & nd \\
\hline
\end{tabular}




\begin{tabular}{|l|c|c|c|c|}
\hline \multirow{2}{*}{$\begin{array}{l}\text { FOOD HOMOGENIZED } \\
\text { FOR ANALYSIS }\end{array}$} & \multicolumn{4}{|c|}{ CONGENER \# } \\
\cline { 2 - 5 } Dried apricots & 187 & 183 & 180 & 170 \\
\hline Cola flavored bev. & nd & nd & nd & nd \\
\hline Orange flavored bev. & nd & nd & nd & nd \\
\hline Lime flavored bev. & nd & nd & nd & nd \\
\hline Beer & nd & nd & nd & nd \\
\hline Red wine & nd & nd & nd & nd \\
\hline White wine & nd & nd & nd & nd \\
\hline Bottled mineral water & nd & nd & nd & nd \\
\hline
\end{tabular}


Table III (a-g). Estimated daily Intake of PCBs from different foods (ng/day).

IIIa

\begin{tabular}{|c|c|c|c|c|c|c|c|c|c|c|}
\hline \multirow{2}{*}{ FOODS } & \multirow{2}{*}{$\begin{array}{l}\text { SAMPLE } \\
\text { SIZE }(g)\end{array}$} & \multicolumn{3}{|c|}{31} & \multicolumn{3}{|c|}{28} & \multicolumn{3}{|c|}{52} \\
\hline & & MEAN & MIN & MAX & MEAN & MIN & MAX & MEAN & MIN & MAX \\
\hline Bread / pizza & 138.6 & 0.51 & 0.29 & 0.73 & 0.96 & 0.21 & 1.72 & 3.99 & 3.99 & 3.99 \\
\hline Pasta & 131.9 & 1.37 & 0.47 & 2.77 & 1.14 & 0.26 & 2.02 & 1.16 & 0.24 & 1.62 \\
\hline Rice & 25.3 & 0.48 & 0.37 & 0.68 & - & - & - & 0.17 & 0.09 & 0.33 \\
\hline Potatoes & 37.5 & - & - & - & 0.31 & 0.30 & 0.32 & - & - & - \\
\hline Beaf & 46.7 & - & - & - & 0.20 & 0.06 & 0.38 & 1.70 & 0.06 & 2.87 \\
\hline Pork & 5.0 & - & - & - & 0.10 & 0.10 & 0.10 & - & - & - \\
\hline Poultry & 36.8 & 2.13 & 2.13 & 2.13 & 0.26 & 0.07 & 0.45 & 1.18 & 1.18 & 1.18 \\
\hline Ham & 27.6 & 0.06 & 0.06 & 0.06 & 0.04 & 0.04 & 0.04 & 0.17 & 0.17 & 0.17 \\
\hline Fish & 34.2 & 4.45 & 1.33 & 7.56 & - & - & - & 5.50 & 0.68 & 15.22 \\
\hline Eggs & 12.5 & 0.99 & 0.91 & 1.06 & - & - & - & 0.39 & 0.3 & 0.48 \\
\hline Milk & 0.1214 & - & - & - & - & - & - & - & - & - \\
\hline Yogurt & 22.0 & 0.16 & 0.16 & 0.16 & 0.21 & 0.19 & 0.23 & 0.25 & 0.23 & 0.26 \\
\hline Cheese & 45.9 & 0.22 & 0.20 & 0.24 & - & - & - & - & - & - \\
\hline Puddings & 43.0 & - & - & - & - & - & - & 0.05 & 0.03 & 0.06 \\
\hline Ice cream & 14.7 & - & - & - & - & - & - & 0.02 & 0.02 & 0.02 \\
\hline Vegetables & 85.2 & 0.85 & 0.18 & 1.70 & 2.32 & 1.10 & 3.95 & 1.31 & 0.85 & 1.69 \\
\hline Legumes & 16.2 & - & - & - & - & - & - & - & - & - \\
\hline Citrus fruit & 69.1 & 0.12 & 0.12 & 0.12 & - & - & - & - & - & - \\
\hline Fresh fruit & 174.9 & 0.82 & 0.82 & 0.82 & 1.35 & 1.35 & 1.35 & 0.55 & 0.55 & 0.55 \\
\hline $\begin{array}{l}\text { Bottled mineral } \\
\text { water }\end{array}$ & 0.659 & - & - & - & - & - & - & - & - & - \\
\hline Soft drinks & 0.035 & 0.02 & 0.02 & 0.02 & - & - & - & 0.02 & 0.01 & 0.03 \\
\hline Beer & 0.027 & - & - & - & - & - & - & 0.01 & 0.01 & 0.01 \\
\hline Wine & 0.084 & - & - & - & - & - & - & 0.05 & 0.04 & 0.05 \\
\hline
\end{tabular}




\section{IIIb}

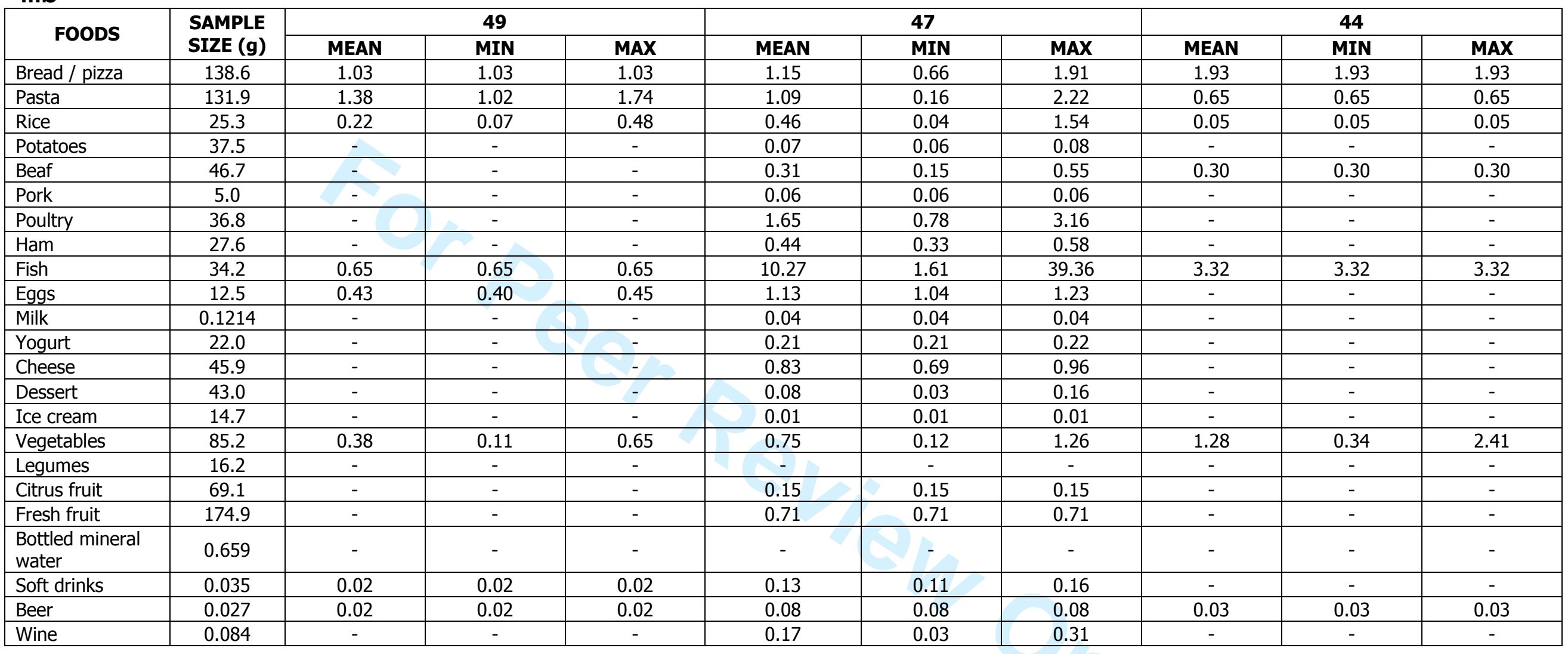


IIIC

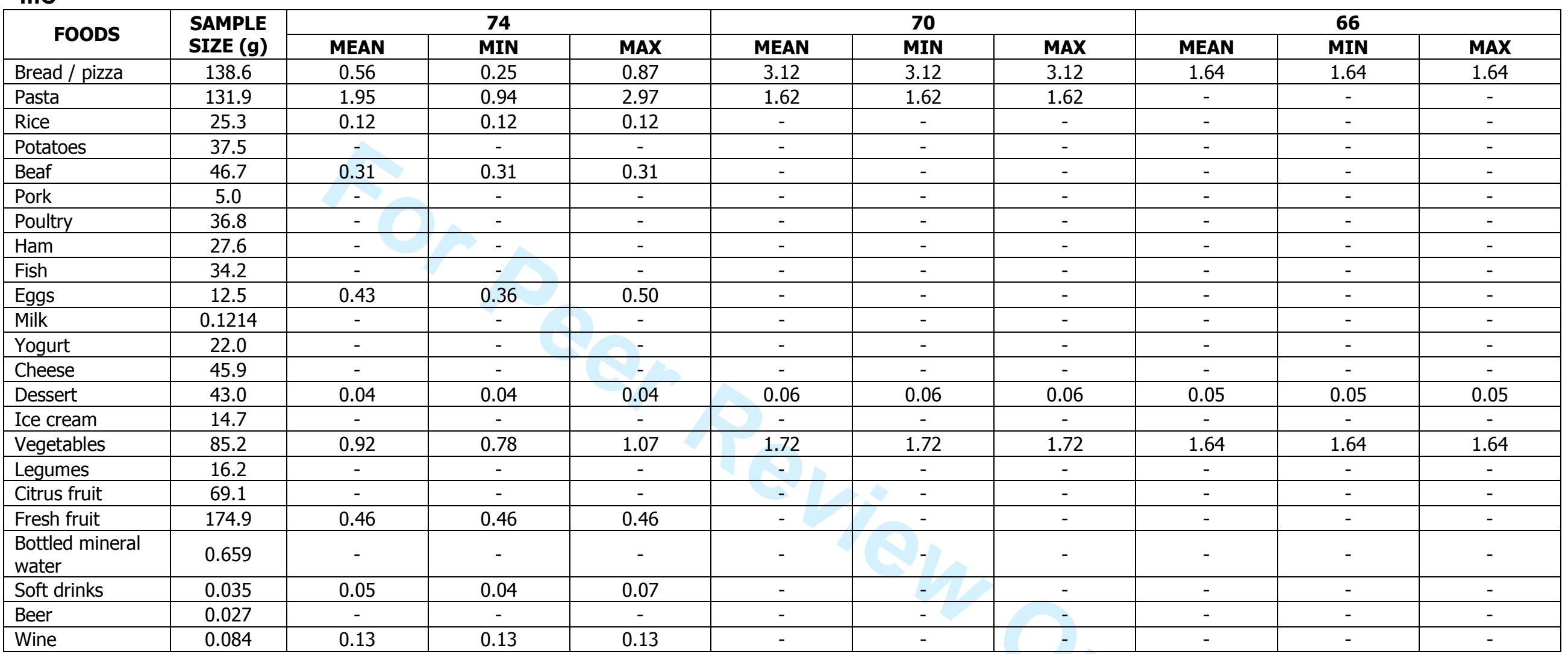




\section{IIId}

\begin{tabular}{|c|c|c|c|c|c|c|c|c|c|c|}
\hline \multirow{2}{*}{ FOODS } & \multirow{2}{*}{$\begin{array}{l}\text { SAMPLE } \\
\text { SIZE (g) }\end{array}$} & \multicolumn{3}{|c|}{101} & \multicolumn{3}{|c|}{99} & \multicolumn{3}{|c|}{110} \\
\hline & & MEAN & MIN & MAX & MEAN & MIN & MAX & MEAN & MIN & MAX \\
\hline Bread / pizza & 138.6 & 4.32 & 3.85 & 4.80 & 2.29 & 2.29 & 2.29 & - & - & - \\
\hline Pasta & 131.9 & 2.64 & 0.98 & 4.52 & - & - & - & - & - & - \\
\hline Rice & 25.3 & 0.65 & 0.17 & 1.59 & 0.10 & 0.10 & 0.10 & 0.30 & 0.30 & 0.30 \\
\hline Potatoes & 37.5 & - & - & - & - & - & - & - & - & - \\
\hline Beaf & 46.7 & 0.40 & 0.24 & 0.50 & - & - & - & - & - & - \\
\hline Pork & 5.0 & 0.03 & 0.03 & 0.03 & - & - & - & - & - & - \\
\hline Poultry & 36.8 & 3.29 & 1.77 & 4.82 & - & - & - & - & - & - \\
\hline Ham & 27.6 & 0.29 & 0.04 & 0.44 & - & - & - & - & - & - \\
\hline Fish & 34.2 & 17.49 & 4.17 & 42.96 & - & - & - & 7.46 & 4.10 & 11.97 \\
\hline Eggs & 12.5 & 1.33 & 1.09 & 1.56 & 0.53 & 0.53 & 0.53 & 0.45 & 0.45 & 0.45 \\
\hline Milk & 0.1214 & 0.01 & 0.01 & 0.01 & - & - & - & - & - & - \\
\hline Yogurt & 22.0 & 0.94 & 0.50 & 1.39 & - & - & - & - & - & - \\
\hline Cheese & 45.9 & 0.53 & 0.46 & 0.60 & - & - & - & - & - & - \\
\hline Dessert & 43.0 & - & - & - & - & - & - & - & - & - \\
\hline Ice cream & 14.7 & 0.05 & 0.05 & 0.05 & - & - & - & - & - & - \\
\hline Vegetables & 85.2 & 2.69 & 0.49 & 5.09 & - & - & - & 2.43 & 0.91 & 3.94 \\
\hline Legumes & 16.2 & - & - & - & - & - & - & - & - & - \\
\hline Citrus fruit & 69.1 & - & - & - & - & 8 & - & - & - & - \\
\hline Fresh fruit & 174.9 & - & - & - & 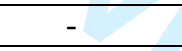 & 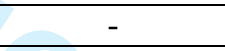 & - & - & - & - \\
\hline $\begin{array}{l}\text { Bottled mineral } \\
\text { water }\end{array}$ & 0.659 & - & - & - & 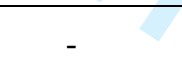 & ( & - & - & - & - \\
\hline Soft drinks & 0.035 & - & - & - & - & - & - & - & - & - \\
\hline Beer & 0.027 & - & - & - & - & - & - & - & - & - \\
\hline Wine & 0.084 & - & - & - & - & - & - & - & - & - \\
\hline
\end{tabular}


IIle

\begin{tabular}{|c|c|c|c|c|c|c|c|c|c|c|}
\hline \multirow{2}{*}{ FOODS } & \multirow{2}{*}{$\begin{array}{l}\text { SAMPLE } \\
\text { SIZE }(\mathbf{g}) \\
\end{array}$} & \multicolumn{3}{|c|}{118} & \multicolumn{3}{|c|}{105} & \multicolumn{3}{|c|}{153} \\
\hline & & MEAN & MIN & MAX & MEAN & MIN & MAX & MEAN & MIN & MAX \\
\hline Bread pizza & 138.6 & 4.984 & 4.984 & 4.984 & 0 & 0 & 0 & 1.019 & 0.374 & 1.732 \\
\hline Pasta & 131.9 & 12.728 & 12.728 & 12.728 & 7.690 & 7.690 & 7.690 & 5.230 & 0.016 & 22.027 \\
\hline Rice & 25.3 & 0 & 0 & 0 & 0 & 0 & 0 & 0.391 & 0.093 & 0.910 \\
\hline Potatoes & 37.5 & 0 & 0 & 0 & 0 & 0 & 0 & 0 & 0 & 0 \\
\hline Beaf & 46.7 & (y) & 0 & 0 & 0 & 0 & 0 & 1.126 & 0.135 & 2.360 \\
\hline Pork & 5.0 & 0.014 & 0.012 & 0.015 & 0 & 0 & 0 & 0.040 & 0.030 & 0.050 \\
\hline Poultry & 36.8 & 0 & 0 & 0 & 0 & 0 & 0 & 2.594 & 0.776 & 7.765 \\
\hline Ham & 27.6 & 0 & 8 & 0 & 0 & 0 & 0 & 0.602 & 0.254 & 0.994 \\
\hline Fish & 34.2 & 0 & 0 & 0 & 0 & 0 & 0 & 7.544 & 1.949 & 21.204 \\
\hline Eggs & 12.5 & 0 & 0 & 0 & 0 & 0 & 0 & 1.994 & 1.750 & 2.237 \\
\hline Milk & 0.1214 & 0 & 0 & 0 & 0 & 0 & 0 & 0.185 & 0.185 & 0.185 \\
\hline Yogurt & 22.0 & 0 & 0 & 0 & 0 & 0 & 0 & 0.471 & 0.347 & 0.561 \\
\hline Cheese & 45.9 & 0 & 0 & 0 & 0 & 0 & 0 & 0.849 & 0.734 & 0.964 \\
\hline Dessert & 43.0 & 0 & 0 & 0 & 0 & 0 & 0 & 0.096 & 0.052 & 0.168 \\
\hline Ice cream & 14.7 & 0 & 0 & 0 & 0 & 0 & 0 & 0.016 & 0.015 & 0.018 \\
\hline Vegetables & 85.2 & 0 & 0 & 0 & 0 & 0 & 0 & 3.831 & 0.230 & 9.968 \\
\hline Legumes & 16.2 & 0 & 0 & 0 & 0 & 0 & 0 & 0 & 0 & 0 \\
\hline Citrus fruit & 69.1 & 0 & 0 & 0 & 0 & 0 & 0 & 0.235 & 0.235 & 0.235 \\
\hline Fresh fruit & 174.9 & 0 & 0 & 0 & 0 & 0 & 0 & 0.210 & 0.210 & 0.210 \\
\hline $\begin{array}{l}\text { Bottled mineral } \\
\text { water }\end{array}$ & 0.659 & 0 & 0 & 0 & 0 & 0 & 0 & 0 & 0 & 0 \\
\hline Soft drinks & 0.035 & 0 & 0 & 0 & 0 & 0 & 0 & 0.043 & 0.043 & 0.043 \\
\hline Beer & 0.027 & 0 & 0 & 0 & 0 & 0 & 0 & 0 & 0 & 0 \\
\hline Wine & 0.084 & 0 & 0 & 0 & 0 & 0 & 0 & 0 & 0 & 0 \\
\hline
\end{tabular}




\section{IIIf}

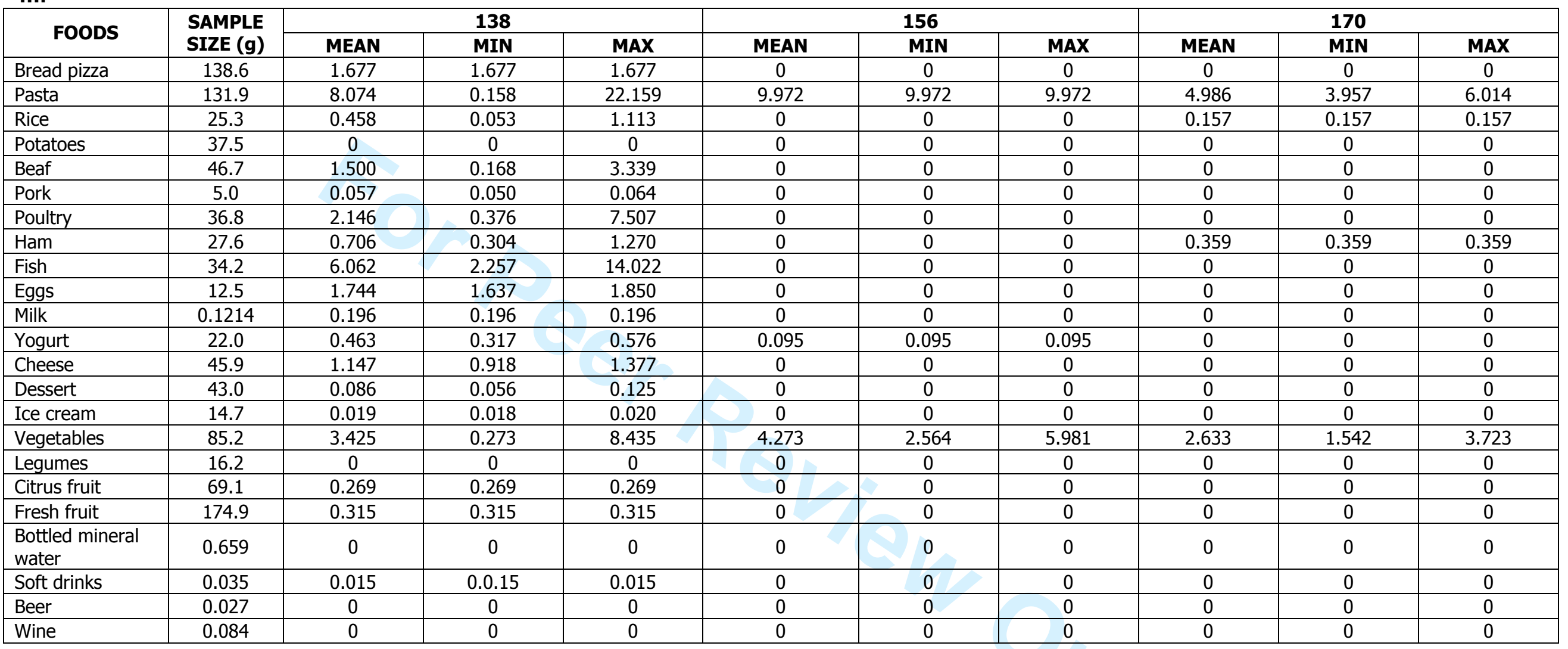




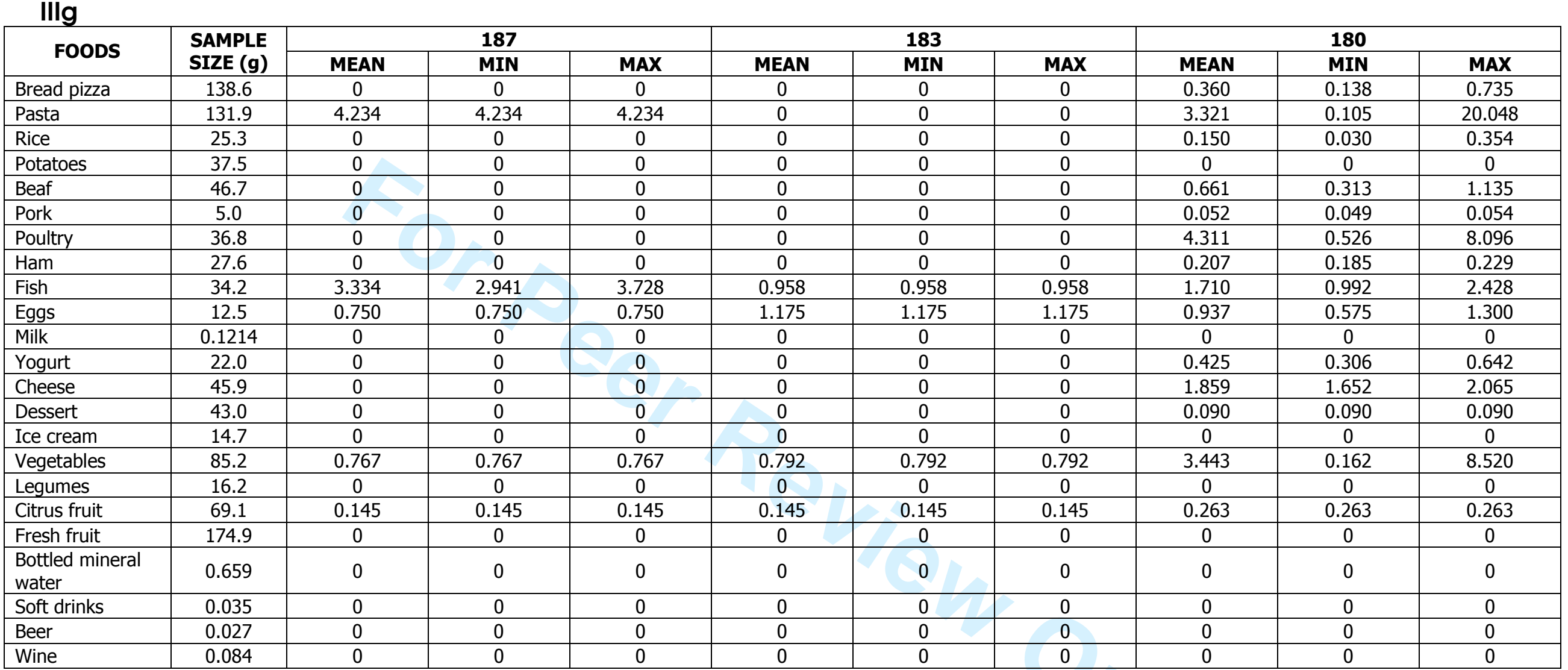




\section{Page 49 of 53}

Food Additives and Contaminants

2

3

5

7

10

11

12

14

15

16

18

19

20

21

23

24

25

26

28

29

30

31

33

35

36

37 
Table IV - Estimated PCBs dietary intake in different countries ( $\mu \mathrm{g} / \mathrm{person} /$ day).

\begin{tabular}{lcc}
\hline Country & $\begin{array}{c}\text { Total daily intake } \\
(\mu \mathbf{g} / \text { person/day })\end{array}$ & Reference \\
\hline Italy (Northern Italy) & 0.26 & This study \\
\hline Japan & $0.166-0.523$ & Koizumi et al., 2005 \\
Japan & $0.7-4.4$ & Akutsu et al., 2005 \\
UK & $0.22-0.46$ & Juan et al., 2002 \\
Italy (Central Italy) & 3.72 & Zuccato et al., 1999 \\
Australia & 6.9 & Kannan et al., 1994 \\
UK & 0.53 & Duarte et al., 1994 \\
India & 0.86 & Kannan et al., 1992a \\
Vietnam & 3.7 & Kannan et al., 1992b \\
Thailand & 1.5 & Tanabe et al., 1991 \\
West Germany & 4.1 & Brunn et al., 1989 \\
Japan & 4.3 & Matsumoto et al., 1987 \\
USA & 1.6 & Gunderson et al., 1988 \\
Finland & 14.4 & Moilanen et al., 1986 \\
\hline
\end{tabular}


Figure 1. Average daily intake (ng/person/day) of 21 PCB congeners from total diet samples collected in Pavia, Northern Italy.

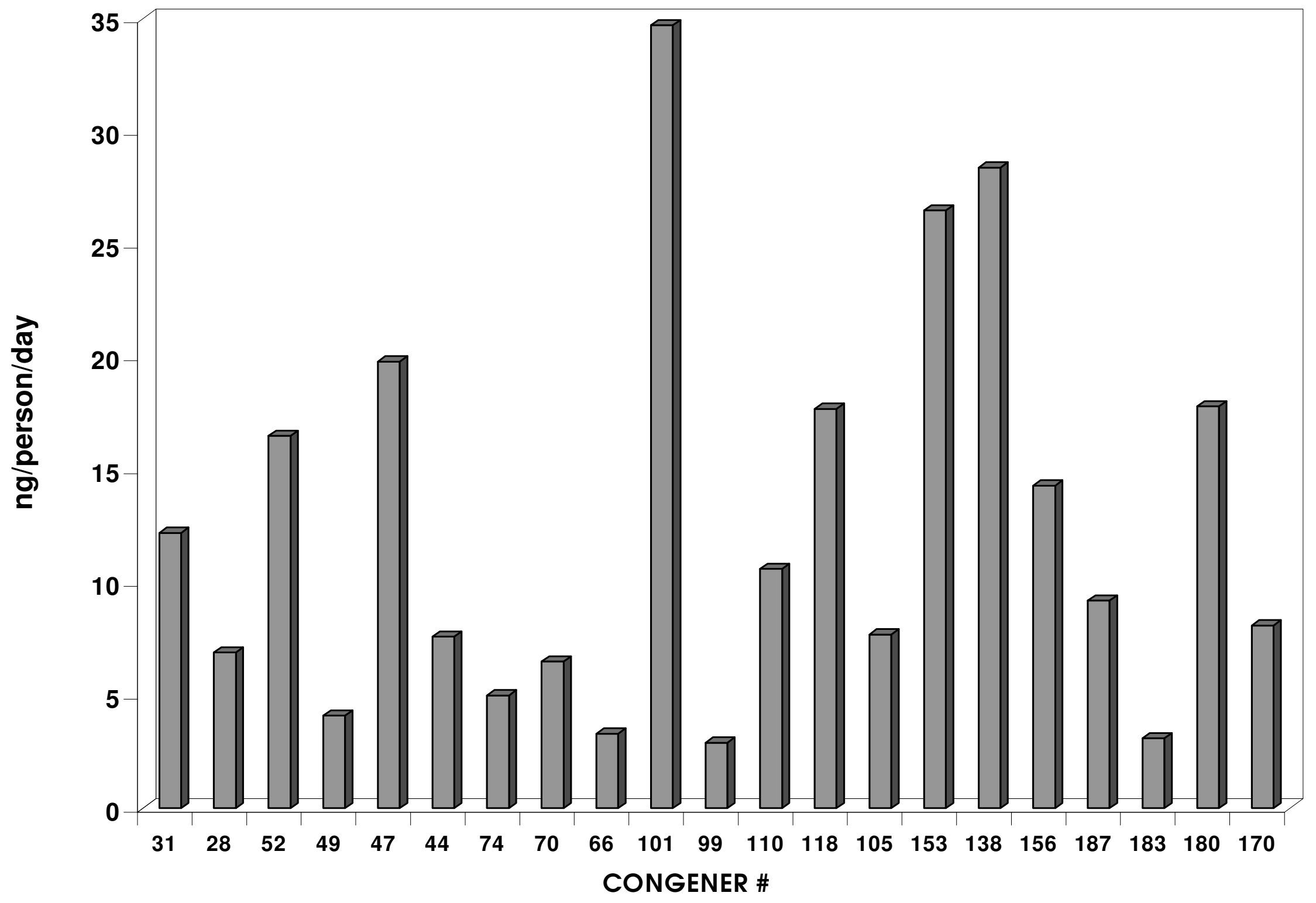

http://mc.manuscriptcentral.com/tfac Email: fac@tandf.co.uk 
Figure 2. Contribution from the different groups of foodstuffs to the dietary intake of 21 PCB congeners.

\section{QBread, œreds, and potaces $\square$ Protein composite $\square$ Dairy produts $\square$ Frit and vegetades $\square$ Beverages}

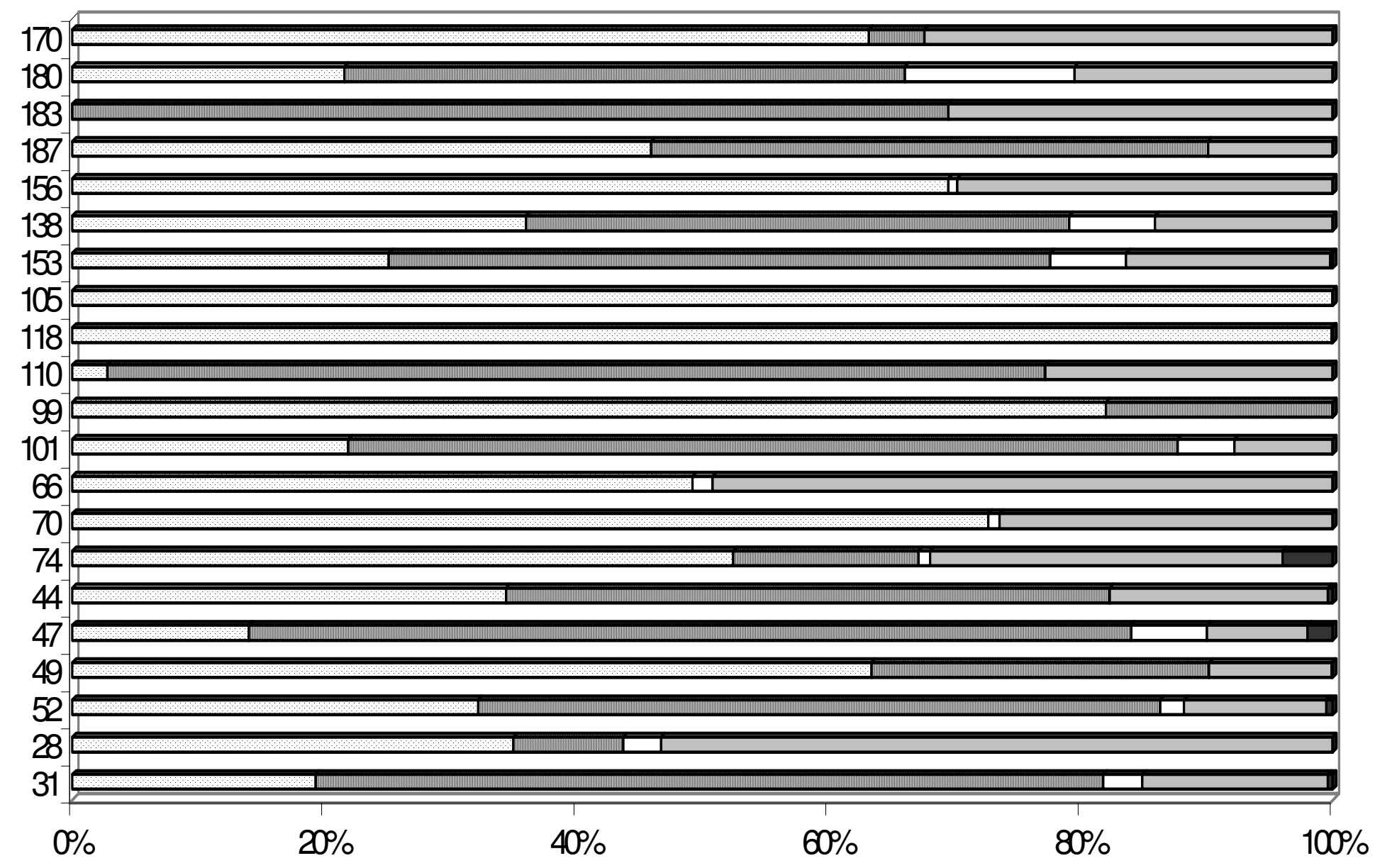


Figure 3. Contribution from different groups of foodstuffs to the dietary intake of TOTAL PCBs (3a) and DIOXIN-LIKE PCBs (3b). Figures in parentheses indicate the percentage contribution.

$\square$ Bread, cereals, and potatoes $\square$ Protein composite

Dairy products

$\square$ Fruit and vegetables

$\square$ Beverages

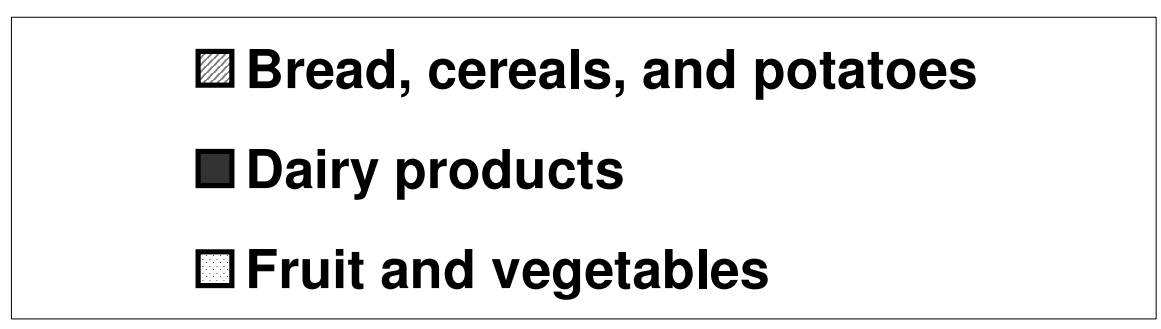

(9.9)

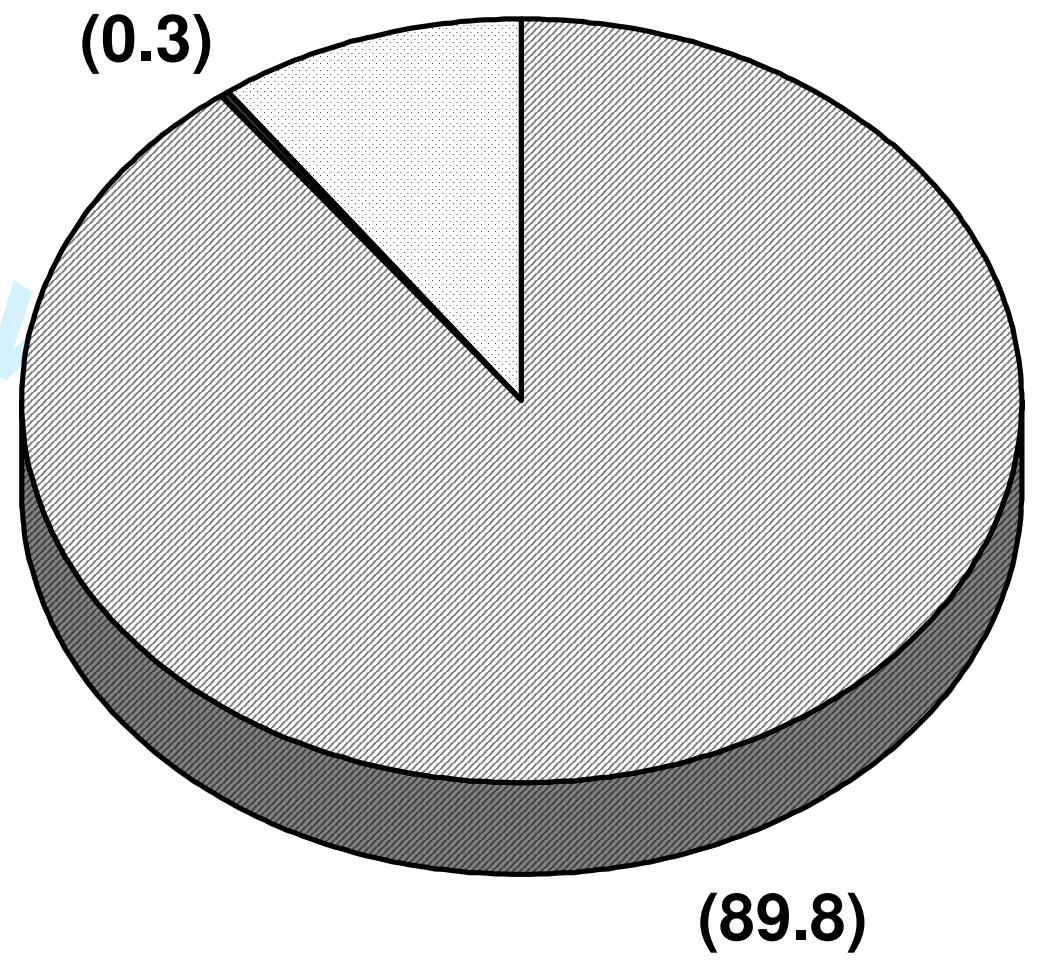

(33.4)

(0.4)

(19.1)

(2.3)

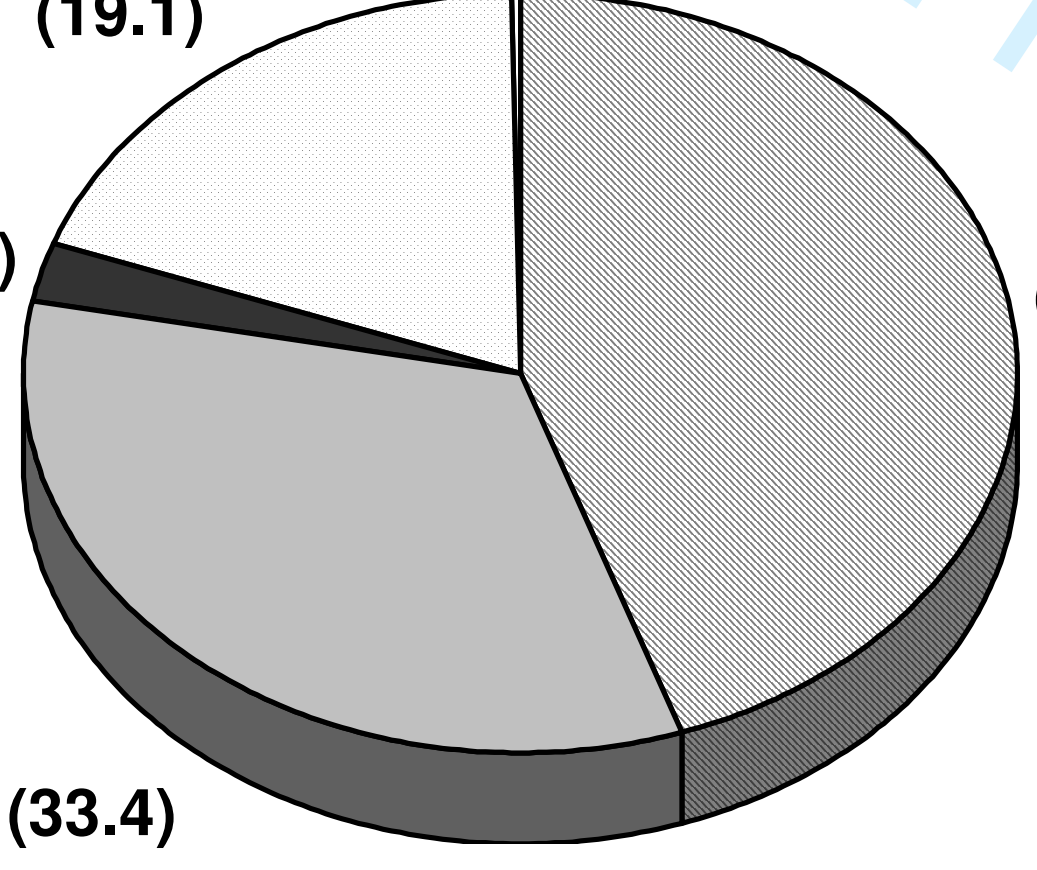

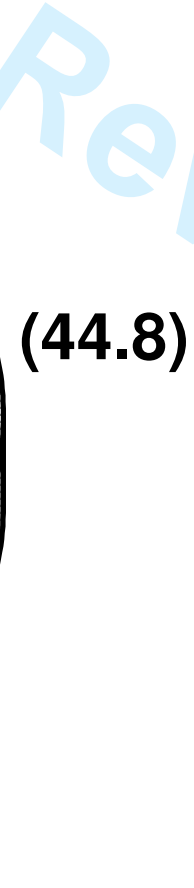

